Louisiana State University

LSU Digital Commons

Faculty Publications

Department of Geology and Geophysics

$5-1-2020$

\title{
The triple oxygen isotope composition of Precambrian chert
}

\author{
Frasier L. Liljestrand \\ Harvard University \\ Andrew H. Knoll \\ Harvard University \\ Nicholas J. Tosca \\ University of Oxford \\ Phoebe A. Cohen \\ Williams College \\ Francis A. Macdonald \\ University of California, Santa Barbara
}

See next page for additional authors

Follow this and additional works at: https://digitalcommons.Isu.edu/geo_pubs

\section{Recommended Citation}

Liljestrand, F., Knoll, A., Tosca, N., Cohen, P., Macdonald, F., Peng, Y., \& Johnston, D. (2020). The triple oxygen isotope composition of Precambrian chert. Earth and Planetary Science Letters, 537

https://doi.org/10.1016/j.epsl.2020.116167

This Article is brought to you for free and open access by the Department of Geology and Geophysics at LSU Digital Commons. It has been accepted for inclusion in Faculty Publications by an authorized administrator of LSU Digital Commons. For more information, please contact ir@lsu.edu. 
Authors

Frasier L. Liljestrand, Andrew H. Knoll, Nicholas J. Tosca, Phoebe A. Cohen, Francis A. Macdonald, Yongbo Peng, and David T. Johnston 


\title{
The triple oxygen isotope composition of Precambrian chert
}

\author{
Frasier L. Liljestrand ${ }^{\mathrm{a}, 1,}$, Andrew H. Knoll ${ }^{\mathrm{a}}$, Nicholas J. Toscab ${ }^{\mathrm{b}}$, Phoebe A. \\ Cohen $^{\mathrm{c}}$, Francis A. Macdonald ${ }^{\mathrm{d}}$, Yongbo Peng ${ }^{\mathrm{e}}$, David T. Johnston ${ }^{\mathrm{a}, 1,}$ \\ ${ }^{a}$ Department of Earth and Planetary Sciences, Harvard University, Cambridge, MA, \\ 02138, USA \\ ${ }^{b}$ Department of Earth Sciences, University of Oxford, Oxford, OX13AN, UK \\ ${ }^{c}$ Department of Geosciences, Williams College, Williamstown, MA, 01267, USA \\ ${ }^{d}$ Department of Earth Science, UC Santa Barbara, Santa Barbara, CA, 93106, USA \\ ${ }^{e}$ Department of Geology Geophysics, Louisiana State University, Baton Rouge, LA, \\ 70803, USA
}

\begin{abstract}
The temperature and chemistry of early seawater have both been inferred from the isotopic composition of Precambrian chert $\left(\mathrm{SiO}_{2}\right)$, a precipitated mineral formed on or within marine sediments. The $\delta^{18} \mathrm{O}$ of chert shows a robust quasi-linear increase through time - a signal that has been interpreted in a number of conflicting ways. For example, changing $\delta^{18} \mathrm{O}$ has been hypothesized to reflect the product of cooling surface ocean temperatures, a signature of evolving seawater $\delta^{18} \mathrm{O}$ composition, or the product of later stage diagenesis (where measured $\delta^{18} \mathrm{O}$ reflects the composition of diagenetic fluids). We suggest this uncertainty can be resolved through the additional measurement and interpretation of the minor oxygen isotope ${ }^{17} \mathrm{O}$ (noted as $\Delta^{, 17} \mathrm{O}$ ) in conjunction with $\delta^{18} \mathrm{O}$. In this study, we present a suite of triple oxygen isotope data on stratigraphically constrained Precambrian chert (both peritidal chert nodules in carbonates and iron formation silica). These mineralogically well-defined data allow for the first stratigraphic tests of the fidelity of ${ }^{17} \mathrm{O}$ in $\mathrm{SiO}_{2}$. We then apply a Monte Carlo resampling technique to test the features of the competing hypotheses noted above, here now including critical constraints from ${ }^{17} \mathrm{O}$. The most parsimonious interpretation of these data suggests that secondary alteration with higher-temperature,
\end{abstract}

Email addresses: liljestrand@fas.harvard.edu (Frasier L. Liljestrand), johnston@eps.harvard.edu (David T. Johnston) 
meteoric-derived groundwater has skewed an original geochemical signature. This treatment can allow for some change in the oxygen isotope composition of seawater itself, however this does not appear to be the most statistically defensible single solution - clearly, some combination of multiple mechanisms is always possible and even likely. What is definitively the case is an equitable, modern-like Archean surface ocean temperature.

Keywords: Oxygen isotope, Chert

\section{Introduction}

The temperature-dependence of the oxygen isotope equilibrium between 3 chemical sediments and seawater was one of the first and still most profound ways isotope geochemistry has been applied toward the understanding of past environments [1]. Famously, the $\delta^{18} \mathrm{O}$ record of foraminiferal carbonates was successfully used to determine the temperature and glacial history 7 of the Cenozoic Era [2, 3]. Deeper in Earth's history, however, it becomes 8 harder to uniquely identify a single process or equilibrium capable of ex9 plaining observed secular changes in $\delta^{18} \mathrm{O}$ records. For example, it is widely

argued (though also debated) that the Precambrian carbonate $\delta^{18} \mathrm{O}$ record is prone to diagenetic alteration [4], which over-writes the primary signal of the depositional environment [5].

Sedimentary chert $\left(\mathrm{SiO}_{2}\right)$ precipitates in temperature-dependent isotope equilibrium with the surrounding seawater or pore waters, and the 3500 million year geologic record of chert $\delta^{18} \mathrm{O}$ captures a structured, quasi-linear increase in preserved compositions [6]. Chert is hypothesized to be more resistant to diagenetic alteration than carbonate (or other phases) and so 
may provide a more reliable record of Proterozoic and Archean environments [7]. This is not to suggest that chert is a perfect recorder, as nodules are commonly polygenic [8], however structured long term variance suggests any $\delta^{18} \mathrm{O}$ alteration is likely second-order to the overall temporal signal. Most directly, the equilibrium temperature-dependence of chert has been used to suggest evolving sea surface temperatures, from a hot Archean world towards our present, equitable climate $[7,9]$. Alternatively, however, the same $\delta^{18} \mathrm{O}$ record can be explained as a proportional change in the $\delta^{18} \mathrm{O}$ of seawater without invoking any change in surface ocean (i.e. precipitation) temperature $[10,11,12]$. Finally, the chert $\delta^{18} \mathrm{O}$ record could reflect progressive diagenetic alteration, overprinting original depositional signals [13]. Of course, each of the three hypothesis is consistent with the chert record, as they are derived directly from it. Thus, additional $\delta^{18} \mathrm{O}$ observations are unlikely to resolve mechanistic questions about the genesis of this record.

Previous research has attempted to address this challenge by coupling the oxygen isotope composition of cherts with other, independent constraints on either temperature or the oxygen isotope composition of seawater. The $\delta \mathrm{D}$ $[7,14]$ and $\delta^{30} \mathrm{Si}$ records of chert [15], and the $\delta^{18} \mathrm{O}$ record of phosphates [16] have all been invoked as Precambrian temperature proxies, but these techniques, while informative, have not resolved the debate. The clumped isotope record of carbonates has been used to constrain the temperature and $\delta^{18} \mathrm{O}$ of Phanerozoic seawater [17], but has yet to provide as sharp of conclusions in the Precambrian $[18,19,20,17]$. Most recently, the $\delta^{18} \mathrm{O}$ of 
sedimentary hematite and geothite [21] suggest changes in the $\delta^{18} \mathrm{O}$ of seawater, and related, the triple oxygen isotope composition of bulk shale [22] point to changes in terrestrial water cycle and associated isotopic compositions. Here, iron minerals carry a lesser temperature dependence on oxygen isotope fractionation, whereas shale data represent a composite of multiple oxygen-bearing phases and complexities therein. In parallel, triple oxygen isotope analysis of altered crustal materials, and ensuing models suggest no change in seawater composition, but rather offer a revision to oceanic crust interactions through time $[23,24]$. With a suite of opposing interpretations derived from similar data, the underlying source of the chert $\delta^{18} \mathrm{O}$ signal is therefore still uncertain.

Measuring the ${ }^{16,17,18} \mathrm{O}$ of Precambrian chert may provide important new insight in this debate. Detailed, high-precision work on geological oxides reveals that chemical sediments carry a resolvable mass-dependent signal that is most sensibly related to the minerals' life histories $[25,22,23]$. The same temperature-dependent equilibrium isotope effects that have been argued to explain the $\delta^{18} \mathrm{O}$ of chert have strict, and definitive, predictions for the companion ${ }^{17} \mathrm{O}$ signal. With that in mind, we report the triple oxygen isotope compositions of a suite of isotopically, mineralogically, and stratigraphically characterized Precambrian chert. The mass-dependent variations in ${ }^{17} \mathrm{O}$ provide an additional axis of variation with which to interpret these now classic $\delta^{18} \mathrm{O}$ records and allow us to distinguish among the three primary hypotheses advanced to explain $\delta^{18} \mathrm{O}$ records. 


\section{Methods}

\subsection{Isotope notation}

The ${ }^{17} \mathrm{O}$ of oxygen-bearing minerals is not routinely measured, as it is often assumed that the $\delta^{17} \mathrm{O}$ carries a constant, mass-dependent offset from the $\delta^{18} \mathrm{O}$. As a result, the extra effort required to acquire ${ }^{17} \mathrm{O}$ data was long thought to carry no additional interpretable signal [26]. However, highprecision fluorination methods have changed this mindset, whereby mass laws and additional information can be gleaned from ${ }^{17} \mathrm{O}$ measurements on massdependent materials. A suite of simple terms then allows for these small mass-dependent effects be quantified and represented visually. At its most simple, the relationship between ${ }^{17} \mathrm{O}$ and ${ }^{18} \mathrm{O}$ during a fractionating process is described by the equation:

$$
{ }^{17} \alpha_{A-B}=\left({ }^{18} \alpha_{A-B}\right)^{\lambda}
$$

where

$$
{ }^{x} \alpha_{A-B}=\frac{{ }^{x} R_{A}}{{ }^{x} R_{B}}
$$

Here, $\mathrm{R}$ is the ratio of the heavy isotope relative to ${ }^{16} \mathrm{O}$. The $\lambda$ is the isotope effect of ${ }^{18} \mathrm{O}$ compared to ${ }^{17} \mathrm{O}$ for a specific reaction. Values for $\lambda$ are approximately 0.5 , but vary at the percent level as a function of process and temperature $[27,28]$. These values range from $\lambda=0.5305$ for hightemperature equilibrium [28] down to $\lambda \approx 0.5$ for the kinetic fractionation 


$$
\Delta^{\prime 17} O=1000 *\left(\ln \left(\frac{\delta^{17} O_{V S M O W}}{1000}+1\right)-\lambda_{R L} * \ln \left(\frac{\delta^{18} O_{V S M O W}}{1000}+1\right)\right)
$$

$$
\delta^{x} O=\left(\frac{\left(\frac{x O}{{ }^{16} O}\right)_{\text {sample }}}{\left(\frac{x O}{{ }^{16} O}\right)_{\text {standard }}}-1\right) * 1000
$$

where $\mathrm{x}$ is 17 or 18 . In order to visualize small variants, $\Delta^{\prime 17} \mathrm{O}$ is employed. Here,

where $\lambda_{R L}$ is the reference line to which the $\delta^{17} \mathrm{O}_{V S M O W}$ values are normalized. We chose to calculate $\Delta^{\prime 17} \mathrm{O}$ using a $\lambda_{R L}$ of 0.5305 because it is a value derived from a thermodynamic prediction, not the average slope of a set of natural samples, and will therefore not change as a consequence of increased or improved measurements. All data provided is placed on a VSMOW scale by replicate measurement of three common calibrated silicates (NBS-28, GMG, and San Carlos Olivine) and anchoring on a GMG value of 5.99 and $-0.102 \delta^{18} \mathrm{O}$ and $\Delta^{\prime 17} \mathrm{O}$, respectively [29, 30, 25, 31, 32, 33, 34, 35].

\subsection{Sample suite}

The target of this work is to assay the long-term change in the oxygen isotopic composition of Precambrian chert in order to evaluate its informa- 
tion richness. To do so, we collected and analyzed 90 chert-bearing samples that range in age from early Paleoarchean to Cambrian, with highest sample density in the Neoproterozoic (see supplemental tables). Within the Neoproterozoic stratigraphy, we also target and perform a stratigraphic test. From these samples, we sub-sampled some rocks with distinct chert phases or nodules, resulting in 105 total sample measurements. Importantly, all these target localities predate the advent of biologically driven opal precipitation, and as such reflect chemical (abiotic) precipitation [36].

A full sample list and locality information is included within the supplement, however two depositional environments dominate the stratigraphy represented. First, most Proterozoic samples reflect peritidal environments, where they precipitated as nodules during early diagenesis [37]. In such environments, supersaturated silica forms an amorphous gel which matures into microcrystaline quartz [38]. Due to the early crystallization, the host fluid in these sediments is often assumed to be comparable in temperature and isotopic composition to the overlying ocean. These are also environments of exceptional microfossil preservation, demonstrating the robust nature of these nodules to post-depositional processes [39]. Juxtaposed to these settings, we also include chert from early Proterozoic and Archean iron formations. Here, the exact depositional environment can vary but is generally basinal, with silica adsorbed onto iron-bearing precipitates from seawater[40, 41, 42, 43]. Other early Archean chert reflect diagenetic alteration of primary sediments, at least in part under the influence of hydrothermal fluids [44]. 


\section{3. chemical methods}

The goal in the chemical pre-processing of each sample was to isolate the quartz fraction from any contaminating oxygen bearing phases. For each sample, approximately 1 gram of chert was subsampled and powdered using a tungsten carbide shatterbox. Where texturally appropriate, multiple subsamples were powdered to access separate nodules or visually distinct textures. The powdered samples were acidified in $2 \mathrm{~N} \mathrm{HCl}$ to remove carbonate phases, then filtered, dried, and baked at $500^{\circ} \mathrm{C}$ to remove organic matter. This leaves $\mathrm{SiO}_{2}$ rich insoluble residue. Detailed mineralogy, on both the pre- and post- acidified samples were conducted at Oxford University (see supplemental tables).

The $\delta^{18} \mathrm{O}$ and $\delta^{17} \mathrm{O}$ of the $\mathrm{SiO}_{2}$ were measured by laser fluorination at Louisiana State University [45] and Harvard University [35]. At LSU, the samples are prefluorinated overnight in a reaction chamber under a $\mathrm{BrF}_{5}$ atmosphere, and then heated by a $30 \mathrm{~W} \mathrm{CO}_{2}$-laser to generate $\mathrm{O}_{2}$. This laser fluorination converts structural oxygen to $\mathrm{O}_{2}$ gas, which is then separated from excess $\mathrm{BrF}_{5}$ and other fluorinated byproducts through a series of liquid nitrogen cryo-focusing steps. The $\mathrm{O}_{2}$ yield, calculated by comparing $\mathrm{O}_{2}$ pressure to the initial mass of chert, is consistently above $90 \%$. The purified $\mathrm{O}_{2}$ is introduced into a separate Finnigan MAT 253 isotope ratio mass spectrometer and analyzed in dual inlet mode. Measurements of silicate standards, NBS-28, UWG-2, and San Carlos Olivine, suggest a reproducibility of $0.3 \%$ and $0.018 \%$ for $\delta^{18} O$ and $\Delta^{17} O$, respectively. At Harvard, the samples are 
again prefluorinated overnight, but combusted by a $50 \mathrm{~W} \mathrm{CO}_{2}$-laser under a pure $F_{2}$ atmosphere. Sample purification is similar to above, however with the inclusion of an in-line gas chromatograph before being directly introduced to a Thermo Scientific MAT 253 gas source isotope ratio mass spectrometer. Repeated measurements of the same silicate standards generated a reproducibility of $0.4 \%$ and $0.015 \%$ for $\delta^{18} O$ and $\Delta^{, 17} O$, respectively. For chert samples analyzed via both methods, the agreement is well under the quoted, conservative, estimates of error from silicate standards (Figure S1, Table S1).

\section{Results}

In the present study, we add to the existing Precambrian record of $\delta^{18} \mathrm{O}$ in chert and expand by including the minor oxygen isotope, ${ }^{17} \mathrm{O}$. As seen in Figure 1, the new measurements of $\delta^{18} \mathrm{O}$ align with previous work. Although the exact nature of the change in $\delta^{18} \mathrm{O}$ through time is debated, the progressive increase in $\delta^{18} \mathrm{O}$ is clear. As our new measurements also capture this trend, the accompanying ${ }^{17} \mathrm{O}$ data can confidently be used to assess the source of the full oxygen isotope signal.

It is critical to appreciate that the fluorination methods used here will access all oxygen-bearing phases within a sample, including any contaminants. As such, we begin with an evaluation of the mineralogical content of the targeted material (Figure 2). Here, about $80 \%$ of the chemically treated samples consisted of more than $90 \%$ quartz. Our chemical preparation method effectively removed carbonate, but the remaining $20 \%$ of samples had significant 


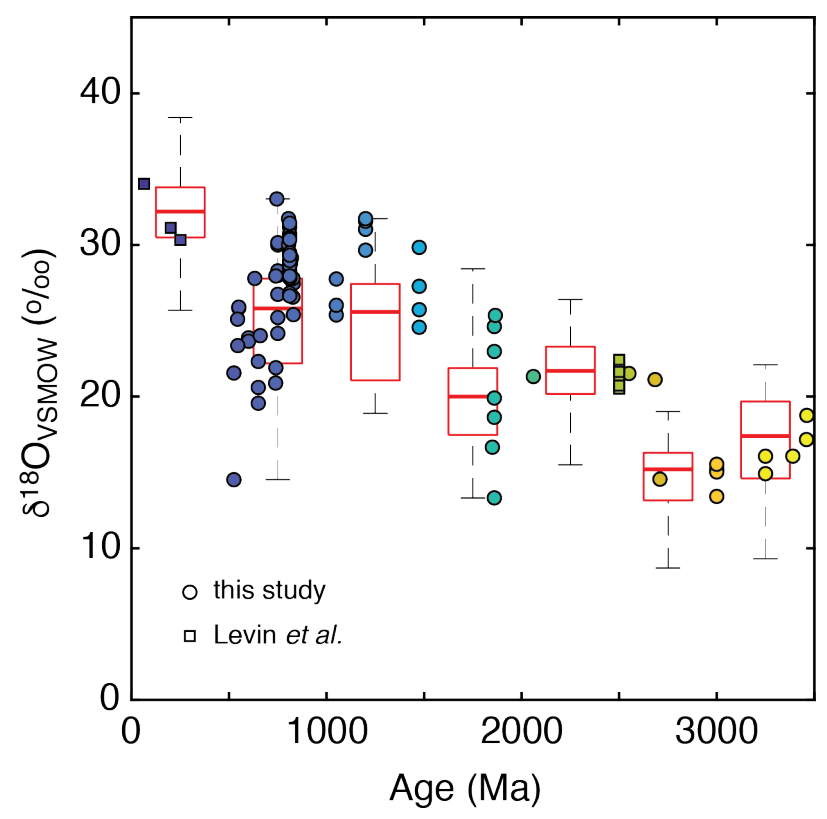

Figure 1: The $\delta^{18} \mathrm{O}$ of chert $(\%)$ relative to Vienna Standard Mean Ocean Water plotted as a function of time. Data points are $\delta^{18} \mathrm{O}$ measurements of chert for which $\Delta^{17} \mathrm{O}$ measurements are available (circles from this study, squares from [25]). Box and whisker plots are additional $\delta^{18} \mathrm{O}$ measurements from previous studies grouped in $500 \mathrm{Ma}$ bins [6]. The central red line shows median value, the box represents the $25^{t h}$ and $75^{t h}$ percentile, the whiskers are 1.5 times the scale of the box. The color coding of the data corresponds to the age of the sample (x axis) and is consistent in subsequent figures. A similar plot highlighting the ${ }^{17} \mathrm{O}$ data is presented in Figure S2.

fractions of primarily clay and iron oxide. These other oxygen bearing phases risk contaminating the primary $\mathrm{SiO}_{2}$ signal. In fact, samples with significant non-silica phases are on average $7.2 \% 0$ lighter in $\delta^{18} \mathrm{O}$ (and only $0.02 \%$ heavier in $\Delta^{\prime 17} O$ ). We thus focus only on the samples with greater than $90 \%$ quartz fraction. It is noteworthy that other environmentally relevant information could be locked within these coexisting mineral phases. The complete mineralogy data is presented in Supplemental materials.

From the now curated dataset, a clear secular increase in the $\delta^{18} \mathrm{O}$ of 
chert is apparent, from Archean compositions averaging below 20\%o toward late Precambrian values above $30 \%$ (Figure 1 ). The corresponding $\Delta^{\prime 17} \mathrm{O}$ composition is consistently negative, ranging from -0.04 to $-0.26 \%$. The negative values are a product of our using $\lambda=0.5305$, the maximum possible slope, as our reference when calculating $\Delta^{17} \mathrm{O}$ and are consistent with the existing literature data [25]. The isotope measurements are presented in supplemental files and Figure 2.
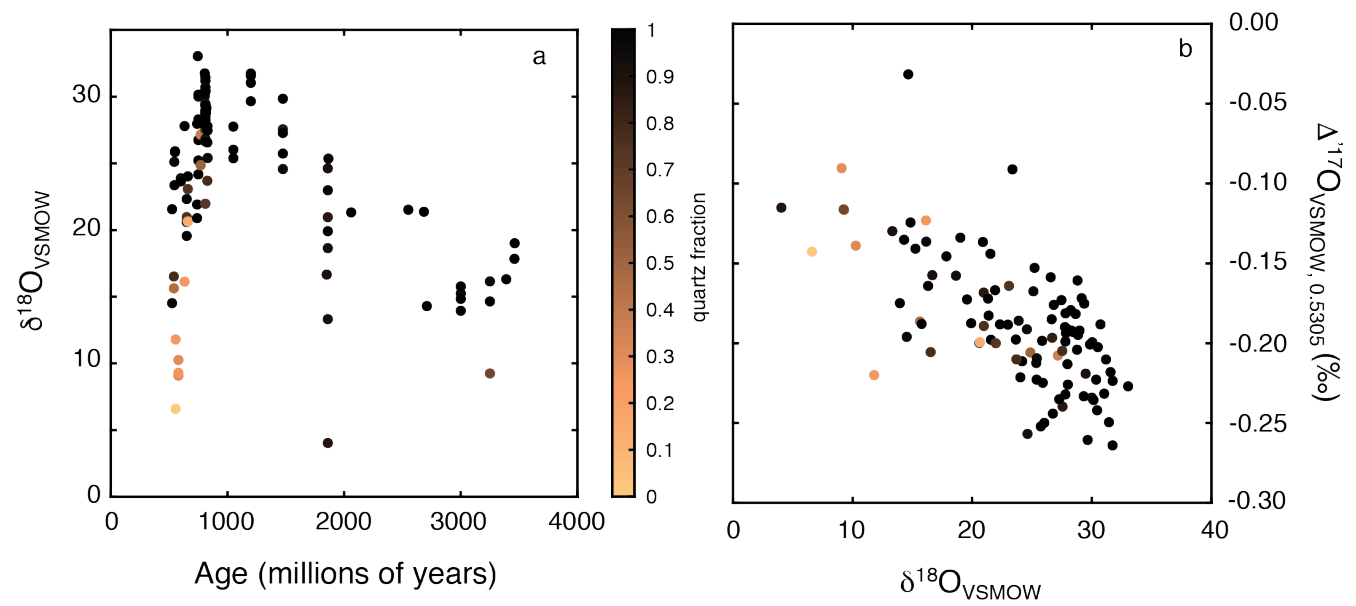

Figure 2: (a) The $\delta^{18} \mathrm{O}$ as a function of time, with (b) $\Delta^{, 17} \mathrm{O}$ as a function of $\delta^{18}$ where individual data are colored according to the quartz fraction of the sample, as measured by XRD analysis. The scale bar for quartz fraction is included between the two frames, and only the black data (composed of more than $90 \%$ quartz) are used in subsequent analysis. Detailed mineralogy of each sample is listed in Table S2.

\subsection{A stratigraphic test: the Fifteenmile Formation}

Before we can investigate the differing models proposed to explain the information locked within the $\delta^{18} \mathrm{O}$ of Precambrian chert, we must first test the scale at which chert is vulnerable to isotopic change. Put simply, if there 
exists a wide compositional range within a given hand sample or across a well mixed paleo-basin, interpreting the same magnitude of signal across geological time would not be prudent. The first test, variability on the hand sample scale, was performed by comparing the isotopic composition of different nodules cut from the same sample. We ran this test 13 times, and the mean offset in $\Delta^{\prime 17} \mathrm{O}$ is $0.004 \%$, with a variance at $2 \sigma$ for our analytical precision. The later of these tests, capturing how robust the ${ }^{17} \mathrm{O}$ in chert is across a single basin, is conducted on the Tonian aged Fifteenmile Formation. We present data from two parallel stratigraphic sections. The lion's share of the samples come from a 20 meter section of Mt. Slipper (section P1401, see [39]). The remainder of the data was generated on samples from the contemporaneous beds within the Fifteenmile, roughly one kilometer away (section P1405, [39]). These data test for variability within a given stratigraphic section and across a paleo-basin. The mean $\Delta^{\prime 17} \mathrm{O}$ from the $\mathrm{P} 1401$ section is $-0.200 \pm 0.022 \%$, whereas section P1405 carried a mean of $-0.206 \pm 0.024 \%$ o (Figure S3) . The two sections are thus statistically indistinguishable, but do carry some resolvable $\delta^{18} \mathrm{O}$ variance. However, this variance is clearly not large enough to manifest in a resolvable, more mechanistic $\Delta^{, 17} \mathrm{O}$ signal. For further context, the reproducibility of standards is near the statistics on these natural populations. Hence, the variability we observe within a single section is indistinguishable from the variability we expect based on our capacity of make precise $\Delta^{17} \mathrm{O}$ measurements. This does not imply that the samples are unaltered, but simply that a cross section of samples at that geographic 
scale can share a loosely similar life history. Indeed, there is resolvable $\delta^{18} O$ variability within the basin, however governing mass laws (or $\lambda$ values) will not manifest an appreciable change in $\Delta^{\prime 17} \mathrm{O}$ over such a small-scale $\delta^{18} O$ range. This would suggest that any alteration process must carry a $\lambda$ between 0.5305 and 0.527 in order not to have generated an accompanying resolvable $\Delta^{\prime 17} \mathrm{O}$. It is noteworthy that meteoric water falls a long a line of 0.528, a point considered more deeply below.

\section{Discussion and Geologic scenarios}

The new data generated through this study are in keeping with previous $\delta^{18} \mathrm{O}$ measurements, these samples can be interpreted as a 'representative' sample suite with which to test pre-existing hypotheses in light of the new $\Delta{ }^{\prime 17} \mathrm{O}$ data. We do so in turn. We first individually consider changes in ocean temperature and the $\delta^{18} \mathrm{O}$ composition of seawater itself, before ending with a discussion of diagenetic over-printing.

\subsection{A change in global temperature}

The new $\delta^{18} \mathrm{O}$ measurements in this study could be explained by a progressive decrease in mean ocean temperature over the last 4 billion years. The decreasing temperature manifests as a change in the equilibrium isotope fractionation factor $\left(\alpha_{\text {chert-water }}\right)$, offset relative to an ice-free ocean of constant composition (calculated as $\delta^{18} \mathrm{O}$ of $\approx-1.2 \%, \Delta^{17} \mathrm{O}$ of $\approx-0.005 \%$; and consistent with $[23,24])$. In this scenario, the median $\delta^{18} \mathrm{O}$ in the Archean 
corresponds to a temperature of over $120^{\circ} \mathrm{C}$, which subsequently evolves to a $38^{\circ} \mathrm{C}$ Phanerozoic ocean. The physical interpretation of this temperature is itself controversial $([14,46,12])$; however, an agnostic approach is to simply address the consistency of the $\Delta^{17} \mathrm{O}$ prediction.

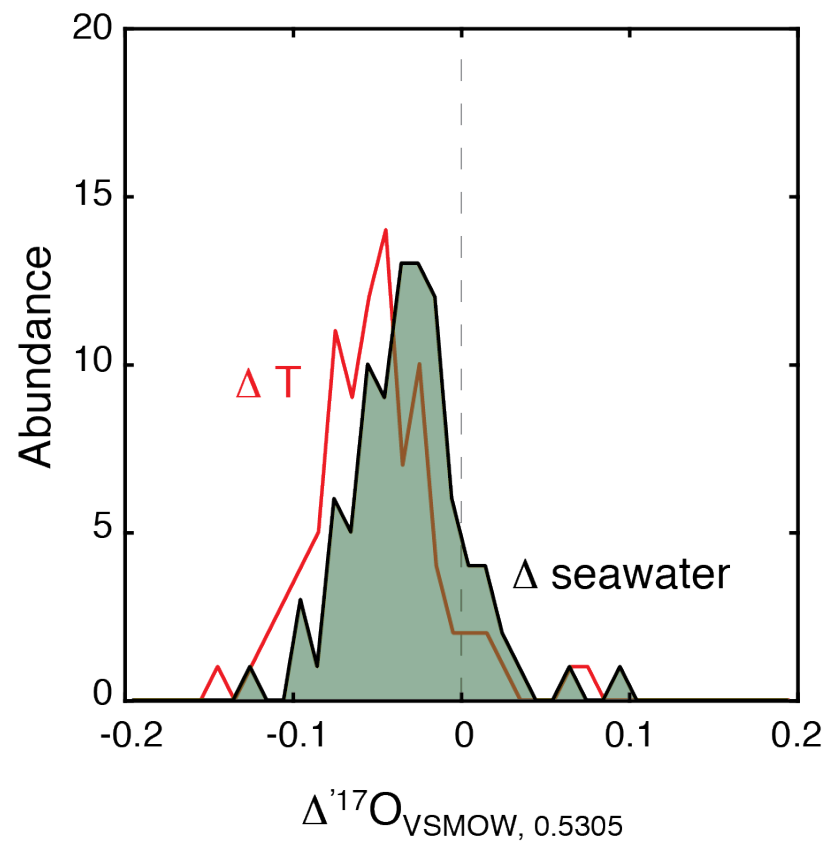

Figure 3: As noted in the text, changes in temperature and the composition of seawater through time make predictions for the associated oxygen isotope composition of seawater. Here, we present the residual, or mismatch, in $\Delta^{17} \mathrm{O}$ between those model predictions and the data presented herein. The red line is the residual population for changing ocean temperatures, whereas the green shaded area is the residual for the evolving ocean $\delta^{18} \mathrm{O}$. A perfect fit, for example, would have a distribution centered on a value of $0.00 \%$. The average value of the ocean $\delta^{18} \mathrm{O}$ change residual is $-0.034 \%$ and the average value of the temperature change residual is $-0.054 \%$. Put differently, these models cannot, as formulated, satisfy the minor oxygen isotope data.

The existing $\delta^{18} \mathrm{O}$ record corresponds to a unique temperature trend through geologic time, and these supposed temperatures in turn predict a corresponding $\Delta^{\prime 17} \mathrm{O}$ composition assuming equilibrium fractionation [33]. 
The equilibrium $\lambda$, which controls the $\Delta^{\prime 17} \mathrm{O}$, becomes smaller at lower temperatures, which ultimately produces a concave downward trend in $\Delta^{17} \mathrm{O}$ versus $\delta^{18} \mathrm{O}$ (see Fig. S4). The degree of variability in $\Delta^{, 17} \mathrm{O}$ does not allow for a test on this predicted concavity, however the measured $\Delta^{17} \mathrm{O}$ are consistently more negative than the predicted trend (on average, $\approx 0.05 \%$ : Figures 3 and S4). Based on this mismatch between predicted and measured compositions, the hypothesis that variability in the chert record is produced strictly by changes in the ocean temperature is not uniquely supported by the $\Delta^{\prime 17} \mathrm{O}$ data.

It is noteworthy that most studies that advocate for elevated temperatures make the additional assumption that the heaviest $\delta^{18} \mathrm{O}$ composition for each time-period, not the median value, reflects the primary composition [15] - this allows for some degree of secondary alteration. Based on this interpretation, the Archean ocean would still be at $70-80^{\circ} \mathrm{C}$, but no longer unrealistically hot. Unfortunately, this interpretive approach does not further minimize the mismatch between predicted and measured $\Delta^{17} \mathrm{O}$ values. Changing the temperature prediction would shift the $\Delta^{, 17} \mathrm{O}$ prediction along an equilibrium fractionation array, but it would not shift the array towards the field of measured compositions (see Fig. S4). The calculated equilibrium $\Delta^{\prime 17} \mathrm{O}$ being offset from the measured data means, regardless of the temperature, a single equilibrium formation process will not capture the bulk of the geologic record. What is less convincing is the efficacy of the temperature model as a solution when placed relative to the other existing hypotheses. 


\section{2. changing the composition of seawater}

Another possible explanation for the change in the $\delta^{18} \mathrm{O}$ of $\mathrm{SiO}_{2}$ through the Precambrian (and by extension, throughout Earth history) is that the actual $\delta^{18} \mathrm{O}$ of seawater is evolving. Here, the equilibrium offset may be unchanged (i.e. no change in surface temperatures), but the apparent effect in chert drifts as a function of changing seawater composition. The $\delta^{18} \mathrm{O}$ of seawater is set by interactions at both high and low temperature with basaltic oceanic crust [47]. High-temperature exchange occurs at ridges and deep in the ocean crust whereas low-temperature exchange happens during weathering of continental crust and upper oceanic crust. This manifests isotopically because high-temperature reactions are characterized by ${ }^{18} \alpha \approx 1.002$ and low temperature reactions are characterized by ${ }^{18} \alpha=1.020-1.045$ as a function of temperature. Continental and oceanic crustal isotopic values are buffered by recycling with a mantle, assumed to be infinitely large with constant $\delta^{18} \mathrm{O}$ composition. Modelling treatments [11] then allow the evolution of seawater by changing the dominant mode of the ocean-rock interaction from low-temperature exchange in the Archean to high-temperature exchange in the present.

Here we rebuild a popular model $[11,48]$ - designed to describe the $\delta^{18} \mathrm{O}$ of carbonate - with the eventual extension to chert ${ }^{17} \mathrm{O}$ to test this hypothesis. This required the usage of a low-temperature ${ }^{18} \alpha=1.028$, which then enables a test of the variable contribution from different weathering regimes. This fractionation factor reflects the kaolinte - water equilibrium at $5{ }^{\circ} \mathrm{C}[49]$, and 


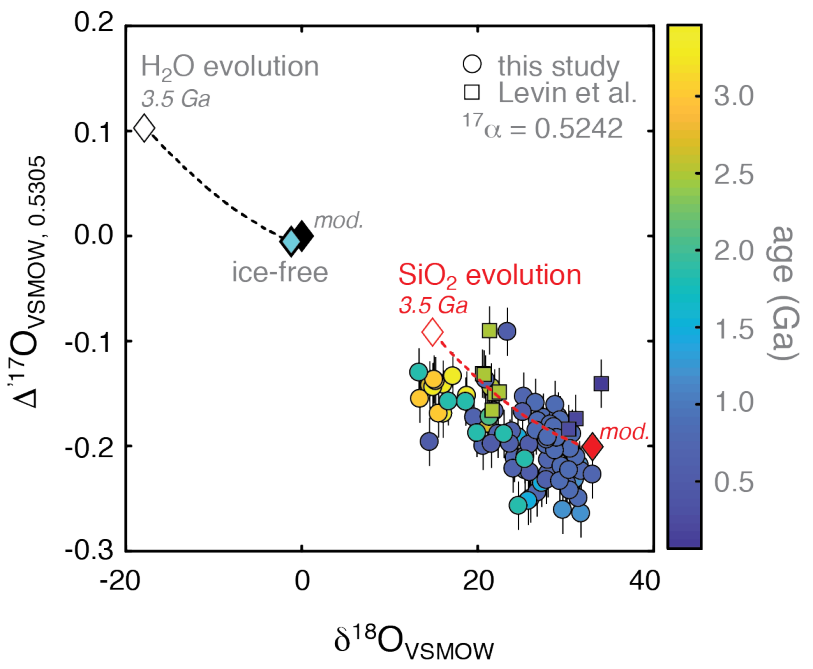

Figure 4: A plot of $\delta^{18} \mathrm{O}$ against $\Delta^{17} \mathrm{O}$. Measured chert compositions are shown, colored according to their age, with error bars reflecting the precision of the $\Delta^{17} \mathrm{O}$ measurement. Error in $\delta^{18} \mathrm{O}$ is smaller than the points. As in Figure 1, data from this study are circles while data from [25] are squares. The composition of VSMOW is $0 \%$ in both $\delta^{18} \mathrm{O}$ and $\Delta^{, 17} \mathrm{O}$ and is represented by the black diamond labeled 'mod.'. The ocean composition change hypothesis posits that seawater $\delta^{18} \mathrm{O}$ increased through time, our geochemical model assigns a $\Delta^{\prime 17} \mathrm{O}$ component to this evolution. The dashed black line shows the compositional change predicted by this model, from $3.5 \mathrm{Ga}$ (white diamond) to the modern ice free ocean composition (cyan diamond). This is similar in directionality, but different in detail from other model predictions [23] based on differing formalism [47]. The dotted red line shows the parallel evolution of a predicted chert composition based on the commensurate change in the composition of seawater. The chert fractionation was calculated to best match the modern isotope offset between chert and seawater.

using a data-derived calibration [23], further allows for the calculation of an associated $\lambda$ of 0.524 . As our results are sensitive to this choice, a number of other scenarios are provided in the supplement (Figure S5). Moving forward, reproducing the entire chert $\delta^{18} \mathrm{O}$ range requires more than $90 \%$ of the Archean ocean crust exchange to occur at low-temperature and more than $90 \%$ of the Phanerozoic ocean crust exchange to occur at high temperature (Figure 3). The test comes with the assignment of ${ }^{17} \mathrm{O}$ fractionation factors 
to each of the geologic pools and to each of the exchange fluxes based on the predicted temperature of that exchange $([31,33,28]$; Fig. S4). This then predicts a $\Delta^{17} \mathrm{O}$ composition of seawater in parallel to the $\delta^{18} \mathrm{O}$ value. The evolving ocean oxygen isotope composition, as well as the chert composition of precipitated chert in equilibrium with that ocean, are shown in Figure 4. Like with the temperature prediction discussed previously, the predicted chert trajectory parallels the triple isotope trend of the data, systematically offset towards more positive values (or leaving a negative residual, see Figure 3). The isotopic mismatch of the changing seawater hypothesis is smaller than the changing temperature hypothesis, but still insufficient by itself as a mechanism for explaining the Precambrian chert record. It is also noteworthy that an unchanged seawater $\delta^{18} \mathrm{O}$ composition is in keeping with Phanerozoic studies of carbonate clumped isotopes [17].

It is worth noting that the slope of the oxygen isotope trajectory of seawater in $\delta^{17} \mathrm{O}-\delta^{18} \mathrm{O}$ space is controlled primarily by the $\lambda$ of the low-temperature exchange processes. If low-temperature ocean-rock exchange is driven using a larger $\lambda$, closer to the high-temperature end-member of 0.5305 , then there would be less contrast in $\Delta^{\prime 17} \mathrm{O}$ between the high- and low-temperature exchange. The oceans $\delta^{18} \mathrm{O}$ could then evolve without changing $\Delta^{\prime 17} \mathrm{O}$, thereby causing the chert trajectory to intercept the bulk of our measurements. Due to the temperature dependence of both $\alpha$ and $\lambda$ it is impossible however to independently change one without affecting the other, and using a larger value for $\lambda$ would require a correspondingly smaller value of $\alpha$, which would 
make it impossible to reproduce the $\delta^{18} \mathrm{O}$ record. This sensitivity is captured in Figure S5.

\section{3. diagenetic alteration}

The previous hypotheses forwarded to explain the isotopic composition of Precambrian chert rely on the capacity of $\mathrm{SiO}_{2}$ to retain a primary depositional signal despite potential later interactions with geological fluids. In fact, in the previously described case where only the heaviest $\delta^{18} \mathrm{O}$ are interpreted for an extracted temperature record, some degree of diagenetic vulnerability is inferred. Great efforts have been taken (cf. [50]) to understand the degree to which the geochemical and isotopic composition of rocks and minerals have been altered through time. The oxygen isotope composition of geologic samples are particularly susceptible to diagenetic resetting given the water-rich, high oxygen content (water at $89 \%$ ) of alteration fluids. This case becomes even more exacerbated when thinking about a largely peritidal facies, which would be subjected in even the shortest term to changes in alteration fluid as a function of sea level change. This proposed diagenetic alteration could come anytime between lithification and the field season the sample suite was collected. A simple stochastic exercise demonstrates such a phenomenon. In a purely synthetic sense, if alteration is random and allowed to occur at variable (random) magnitudes and rate through time, a time-dependent record (Figure 5) is predicted. Importantly, this exercise is devoid of geological observables, but demonstrates alteration-potential and 
as meant as simply an example.

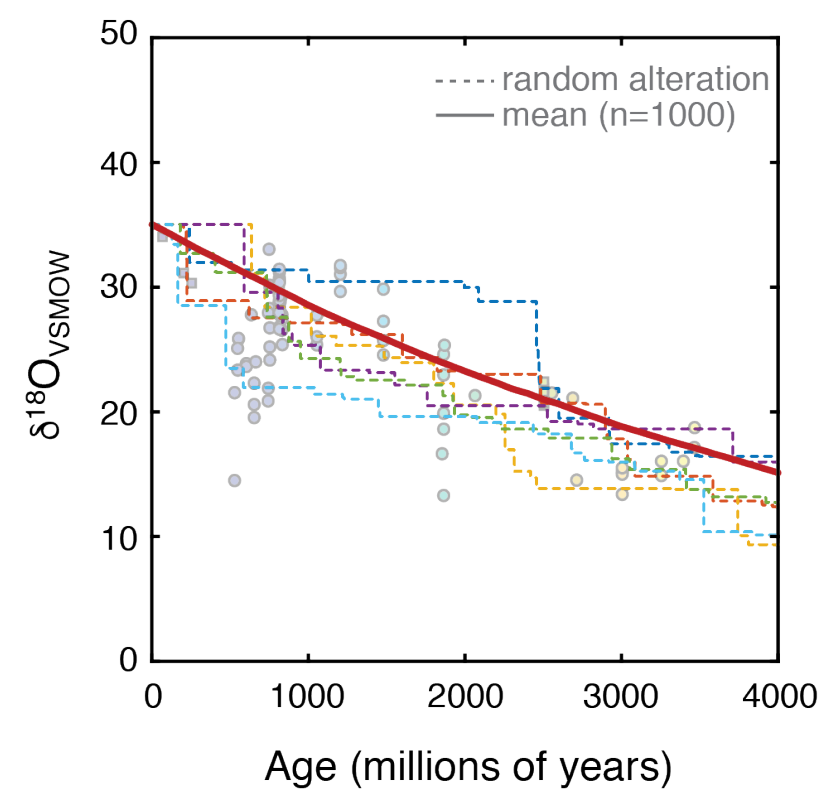

Figure 5: Here we present the results of a random alteration model designed to test the capacity of diagenesis to reproduce the chert $\delta^{18} \mathrm{O}$ record. Model chert precipitated with an initial $\delta^{18} \mathrm{O}$ of $35 \%$ (y-axis), then, with random intervals and magnitude, become altered over time (x-axis). In gray is the $\delta^{18} \mathrm{O}$ data from this study. Colored lines reflect six examples of individual model simulations, and the heavy red line is the mean of 1000 simulations. This simply demonstrates that random alteration, more likely as the age of the geological unit increases, can produce the sort of first order signal preserved in the chert (and other oxygen bearing phases) record(s).

Diagenetic alteration generally carries a non-unique, rather than specific prediction for the isotopic composition of chert. The most basic approach is first adopting the null hypothesis that all $\mathrm{SiO}_{2}$ precipitated with an isotopic composition comparable to today, and any deviation from this composition is the result of alteration. From here, three primary variables control the ultimate composition of chert: the temperature and isotopic composition of the secondary fluid, and the degree of alteration (water to rock ratio). Not 
surprisingly, each variable can be tuned to reproduce the geologic record of $\delta^{18} \mathrm{O}$ and $\Delta^{\prime 17} \mathrm{O}$.

Like $\delta^{18} \mathrm{O}$, diagenesis carries a suite of predictions for the associated $\Delta^{\prime 17} \mathrm{O}$. Here, mixing between two isotopic compositions produces a concave upward array, distinct from equilibrium fractionation lines. The curvature becomes more pronounced as the two end-members become more isotopically different. Due to the concavity, mixing between a modern-like initial chert composition and $\mathrm{SiO}_{2}$ reset by interactions with higher-temperature fluids can easily satisfy the $\delta^{18} \mathrm{O}$ and $\Delta^{\prime 17} \mathrm{O}$ of Precambrian chert. As discussed more below, this is in part because of the flexibility in parameters noted above, which allow the data to essentially be fit, minimizing the residual between model predictions and the data.

The model fit serves to inform the mechanisms acting on the original isotopic composition of $\mathrm{SiO}_{2}$. It is apparent that alteration with a fluid carrying a modern seawater-like composition does not best fit the Precambrian data. Early diagenesis at some stage in the life-history of the sedimentary unit may indeed be seawater-buffered, but later diagenesis can be driven by fluids sourced from meteoric water with highly variable compositions [51]. Alteration with meteoric water has two important consequences in the context of this hypothesis. First, this fluid is lighter in $\delta^{18} \mathrm{O}$ than seawater, thereby forming a larger mixing curve with the primary chert that subsequently results in more negative $\Delta^{17} \mathrm{O}$ compositions. Second, meteoric water has a range of compositions rather than a unique value, therefore producing a field 
of possible solutions rather than a single unique solution. The single mixing line which minimizes the residual between model and data, shown in Figure 6, defines the initial chert to be precipitated at $30^{\circ} \mathrm{C}$ and have been altered by a fluid (likely groundwater) groundwater with a $\delta^{18} \mathrm{O}$ composition of $-16.5 \%$. Importantly, resampling allows meteoric water to freely vary from $-25-0 \%$, and the $-16.5 \%$ is simply the best bulk fit to the entire dataset. These bestfit values are reasonable on the modern Earth, and this solution supports a uniformitarian perspective of Earth history whereby the temperature and isotopic composition of the ocean has remained relatively stable.

The possibility of alteration is not a bi-modal distinction, but the suggestion that more than a primary depositional condition is recording in the composition of the targeted chert. Admittedly, this hypothesis suggests that some primary geochemical information is irrevocably lost. However, even the most altered Archean samples only experienced a W-R ratio of 1 (here we use a classic definition of water:rock, and is discussed in detail below), and thus the majority of the signal is still primary. While it will be difficult to identify a unique initial composition for any individual chert, especially without a tightly constrained composition of alteration fluid, a substantial fraction of the signal remains.

\section{4. a multivariate approach}

Part of the difficulty in distinguishing between the three primary hypotheses surrounding the long-term change in $\delta^{18} \mathrm{O}$ is that they are not mutually 


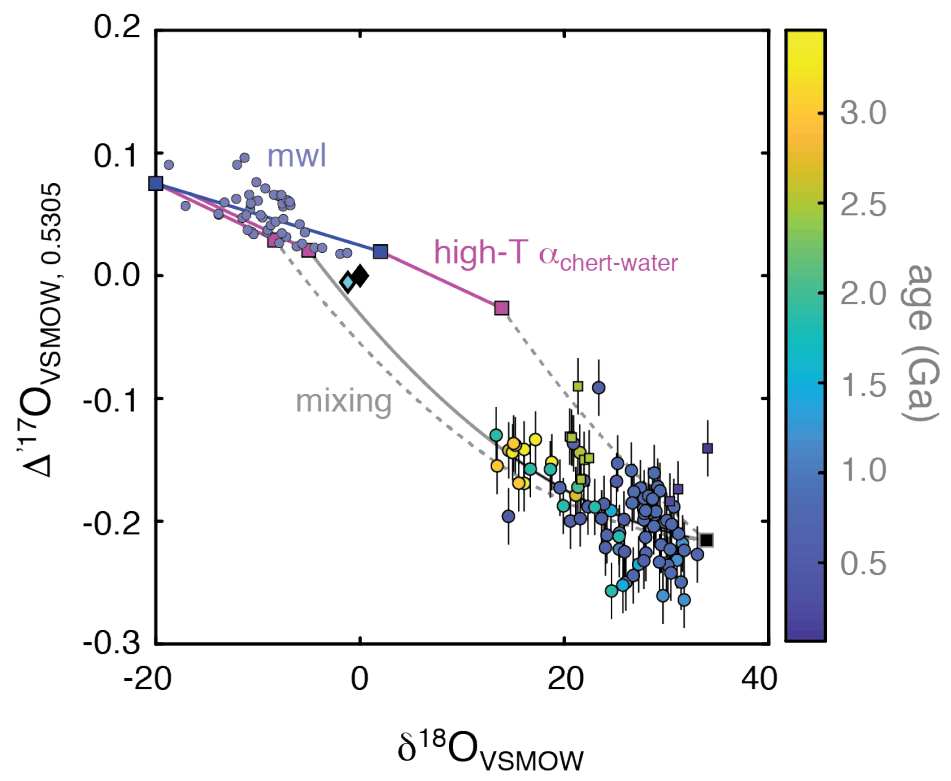

Figure 6: Here we show an alteration model where a primary chert composition precipitated from an ice free ocean, shown as the blue diamond, is altered at high temperature by meteoric water. Meteoric water compositions and blue best fit line (mwl: meteoric water line) from [52]. The offset from this line, set in magenta, is the high-temperature equilibrium fractionation factor for the new, now modified $\mathrm{SiO}_{2}$ composition. This offset is defined as the equilibrium prediction at $200^{\circ} \mathrm{C}$. The dotted grey lines show the mixing (alteration) line between the primary chert composition and various meteoric water compositions. The black line is the mixing line that minimizes the residual between the model prediction and the measured data (colored data points). The best fit for the entire dataset is defined by a water value of $-16.5 \%$, alteration at $200^{\circ} \mathrm{C}$, and a primary precipitation temperature of $30^{\circ} \mathrm{C}$, but varying these parameters would allow for the flexibility to fit the outlying data.

exclusive. All three mechanisms could, in conjunction, influence the $\delta^{18} \mathrm{O}$ and $\Delta^{, 17} \mathrm{O}$ composition of the sampled chert. Above, we analyzed the hypotheses in isolation, showing how the mechanisms would be expressed in $\Delta^{\prime 17} \mathrm{O}$ - this suggested that diagenetic alteration provides the most statistically robust single answer. This comes as little surprise, given the flexibility (in parameter space) associated with that solution. Moving forward, however, 
we can evaluate the relative contribution of these different environmental solutions/parameters in parallel.

Here we provide a synthetic resampling routine that allows all of the features of interest to vary within reasonable bounds. The variables, shown in Table S3, include 1) the degree of ocean evolution, 2) the degree of glacial or evaporative seawater distillation, 3) the temperature of precipitation, 4) the temperature of the alteration fluid, 5) the composition of the alteration fluid, and 6) the degree of alteration (water to rock ratio). The final chert composition is calculated using the equation:

$\delta^{1 x} O_{c-\text { altered }}=\frac{W / R *\left(\left(\alpha_{f-c, h i g h-T}-1\right) * 1000+\delta^{1 x} O_{f, l o w-T}\right)+\delta^{1 x} O_{c, l o w T}}{W / R+1}$

where $\mathrm{W} / \mathrm{R}$ is the water to rock ratio, the superscript $1 \mathrm{x}$ represents either ${ }^{18} \mathrm{O}$ or ${ }^{17} \mathrm{O}$, the subscript $\mathrm{f}$ represents the alteration fluid, hight- $\mathrm{T}$ and low- $\mathrm{T}$ relate to temperature, and the subscript c represents the chert. This style of resampling analysis provides information about both what variables are most likely to control the output isotopic composition and also over what range of values each variable is most likely to cover.

In this approach, the analysis uniformly generates random values for the six primary variables and derives a predicted chert $\delta^{18} \mathrm{O}$ and $\Delta^{\prime 17} \mathrm{O}$ composition for that combination of variable inputs. If the calculated synthetic chert composition corresponds to an actual measured chert composition in the 
dataset to within $0.1 \%$ for $\delta^{18} \mathrm{O}$ and $0.01 \%$ for $\Delta^{, 17} \mathrm{O}$ (conservative bounds, given our uncertainty), the values of the six variables are saved in association with that chert sample. This generates a curated suite of variable sets, or mathematically viable solutions for each individual data point. In fact, each datum is described by many sets of the six variables. As with a Monte Carlo resampling regime, the curated results will carry a distribution that reflects the specificity or sensitivity of that variable to the overall chert composition. The superposition of these individual datasets captures the average environmental conditions required to reproduce the Precambrian triple oxygen isotope composition of chert. This analysis was run $5 \cdot 10^{7}$ times, with $3.5 \%$ of the random solutions satisfying the composition of at least one measured value. The full, uncurated field of solutions is presented in Figure 7, with our measured data plotted on top of it.

The synthetic resampling routine generated a field of interesting, and interpretable information. Figure 8 provides a probability density function for each of the parameters tested. Let us first note how to interpret these fields. The value in the $\mathrm{Y}$ axis (the density function) is the accounting for how many solutions existed for a given $\mathrm{x}$ axis value. Here, solutions are those sets of model inputs that can satisfy any of the given chert compositional measurements. In essence then, the histograms in Figure 8 are recast and summed versions of heat maps like that presented in Figure 7. In cases where the histogram carries structure, there is a specificity within that parameter space necessary to account for the observed chert compositions. In the cases 


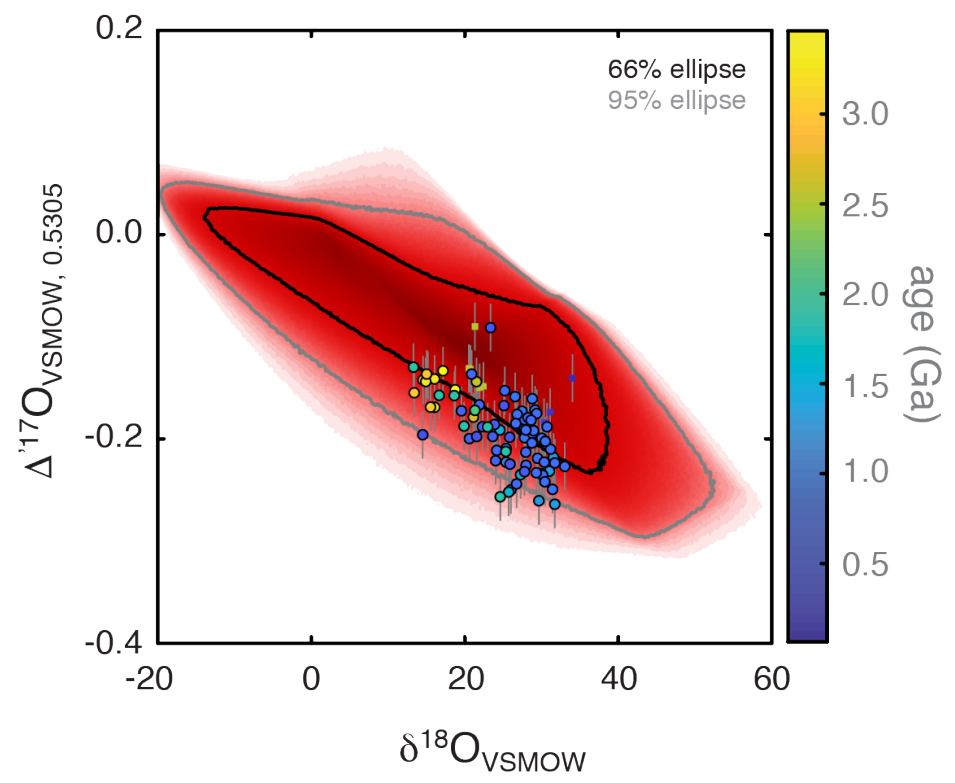

Figure 7: A plot of $\delta^{18} \mathrm{O}$ vs $\Delta^{117} \mathrm{O}$ showing the complete probabilistic results of the stochastic model, in red, compared to the measured chert isotope data. The shade of red reflects the density of model solutions for that unique composition - darker indicates that an increased fraction of the random inputs produced chert with that composition. The tested variables and values thereof are presented in Table S3. The grey and black envelopes show the position of $95 \%$ and $66 \%$ of the results respectively. The centroid of the synthetic results plots above the measured data because, as established in the main text, temperature and ocean change driven fractionations produce $\Delta^{17} \mathrm{O}$ values more positive than the measured data.

where little structure is present (i.e. a flat line), that variable - according to this analysis - does not carry much sensitivity or likelihood of contributing to the overall preserved chert values. Of the histograms shown, some directly correspond to the three primary hypotheses discussed above. First, Figure 8a, in blue, shows the predicted equilibrium precipitation temperature, which in our model corresponds to contemporaneous ocean temperatures. Here the suggestion is for an equitable, modern-like climate where the median seawater temperature varies around about $23{ }^{\circ} \mathrm{C}$. Few solutions recorded elevated 
primary surface ocean temperatures. Next, and as captured in Figure 8b, in red, we evaluate the chances that changes in the $\delta^{18} \mathrm{O}$ of seawater itself are actually driving the observations captured in the chert record. Values of zero reflect a constant ocean $\delta^{18} \mathrm{O}$ composition through time, whereas a value of 1 reflects an ocean that evolves parallel to the chert data. Negative values scale similarly, with the prediction of decreasing $\delta^{18} \mathrm{O}$ of seawater through time. Interpreting this variable brings with it more ambiguity, as the data can all be satisfied without a change in seawater $\delta^{18} \mathrm{O}$, however some moderate change to low:high temperature alteration does describe the median solution. As alteration hypotheses regarding the balance of high and low temperature weathering regimes through time are rooted in geophysical arguments related to heat loss, the likelihood of an intermediate state or weathering balance/solution should be evaluated on those grounds ${ }^{1}$. Small changes in seawater $\delta^{18} \mathrm{O}$ and $\Delta^{\prime 17} \mathrm{O}$ can also be accommodated with variable ice volume, captured in Figure 8f, but the data is better fit with a modest glacial fraction.

Finally, Figure 8c-e in green captures the principle components of diage-

\footnotetext{
${ }^{1}$ With respect to seawater $\delta^{18} \mathrm{O}$ evolution through time (Figure $8 \mathrm{~b}$ ), the analysis has seemingly little dependence on this constraint. However, to further probe the model of [11], the model was run twice, with the glacial fraction defined as 0 and the ocean evolution defined as either 1 or 0 . The ocean with evolving isotopic composition had only $77 \%$ as many model solutions as the isotopically "constant" ocean. Additionally, the evolving ocean model did not produce solutions for 10 of the measured samples, whereas the "constant" ocean carried solutions for all but 4 measured samples. These results further suggest that an isotopically evolving ocean can adequately reproduce the measured data, but an ocean of constant composition is better statistically supported.
} 

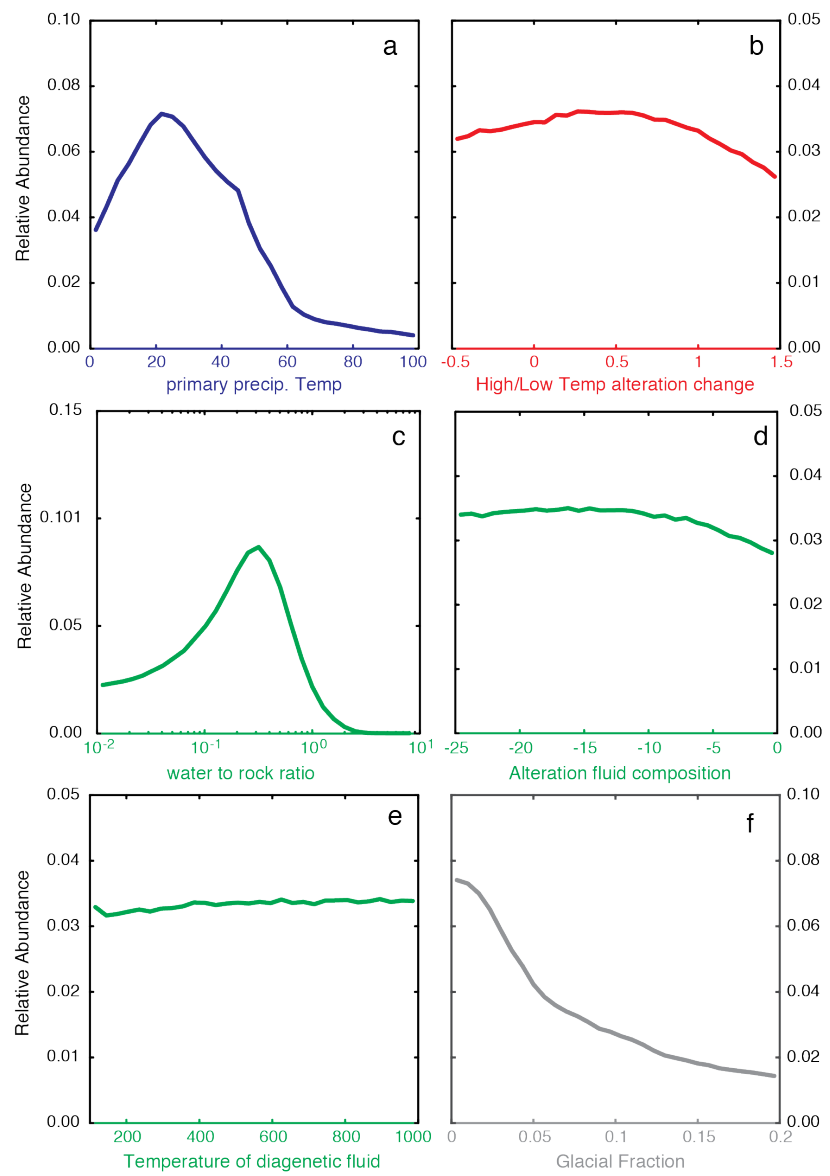

Figure 8: Monte Carlo model results for each tested variable. In each plot the $\mathrm{x}$ axis shows the allowed range of variation for the random input variable, the y axis shows the relative abundance of that value among inputs that reproduced measured data. Each histogram is composed of the compiled fits for all measured data points. Line colors represent the primary hypothesis each variable tests, blue for the warm early ocean hypothesis, red for the ocean $\delta^{18} \mathrm{O}$ evolution hypothesis, green for the diagenesis hypothesis, and grey for glaciation. Although we do not discuss the role of glacial ice, we include it for the sake of being complete. The water to rock ratio shown in $\mathrm{c}$ is displayed with a logarithmic $\mathrm{x}$ axis, but like with the other variables, the inputs are generated such that each value in this plotted space is equally probable. 
nesis. For instance, we present predictions for water to rock ratio, alteration fluid composition and temperature. The W-R prediction suggests that, while some chert can be explained as relatively unaltered - i.e. W-R ratio below 0.1 - the large majority require diagenetic resetting. Further, the predictions here is that alteration occurred at higher temperatures (where equilibrium fractionation factors vary less per unit temperature) with fluids of a meteoriclike composition - none of which is geologically unreasonable. There is an important linkage here between the temperature predictions and geologic observables. We define high-temperature alteration as elevated over seawater temperatures, but still could be as low as a couple hundred degrees (or less). Thus, scaling to something like metamorphic grade is challenging. Finally, there is also more information to potentially gain as narrower time domains are treated independently, as opposed to approaching the dataset as a whole. Although interesting, these results are in keeping with the overall story forwarded from the analysis of the entire dataset (Figure S6).

Simply presenting a histogram of compiled $\mathrm{W}-\mathrm{R}$ ratios as in Figure $8 \mathrm{c}$ is not sufficient to establish that variable alteration drives the classic chert $\delta^{18} \mathrm{O}$ record. We must show that the progressively lighter $\delta^{18} \mathrm{O}$ compositions are matched in the model with progressively more alteration. To do this we found the median predicted $\mathrm{W}-\mathrm{R}$ ratio for each datapoint in our resampling model, the value that is most representative of the degree of alteration, and plotted it against the measured $\delta^{18} \mathrm{O}$ (Figure 9). No corresponding relationship exists between $\delta^{18} \mathrm{O}$ and the modeled precipitation temperature (Figure $\mathrm{S} 7$ ). This 


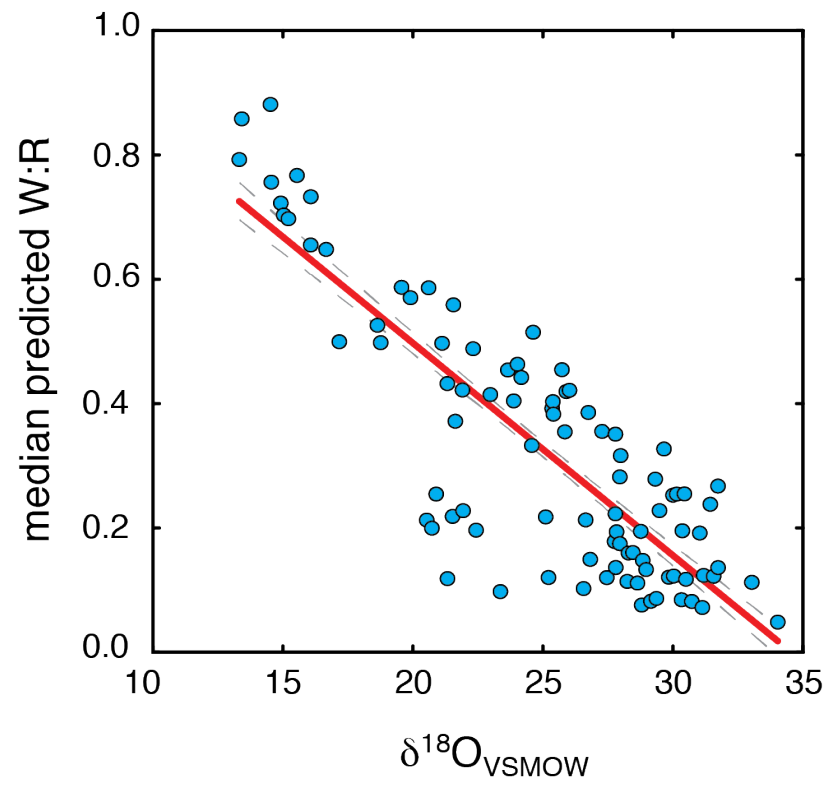

Figure 9: The measured $\delta^{18} \mathrm{O}$ of the chert (x-axis) against the best fit of the modeled Monte Carlo W-R ratio (y-axis) for each chert measurement. Red line shows the linear best fit and suggests that different degrees of alteration produce the observed variation in $\delta^{18} \mathrm{O}$. 
result shows that the $\delta^{18} \mathrm{O}$ and $\Delta^{\prime 17} \mathrm{O}$ records in chert have an important diagenetic component, a conclusion that could not be reached with $\delta^{18} \mathrm{O}$ record alone.

\section{Conclusion}

The oxygen isotopic composition of Precambrian chert has long stood as one of the most robust empirical records of Earth surface change, but interpretations of this record are mired in controversy. Complicating these interpretations is the observation of similar temporal patterns in the oxygen isotope composition of Precambrian phosphate, iron oxide, carbonate minerals, as well as bulk shale. Further, arguments based on Si [53] and D/H [14] isotopes within chert must be accommodated by any prescribed life history of this material required for the $\mathrm{O}$ isotopes.

Here we provide another isotopic axis along which to test these various hypotheses - the inclusion of ${ }^{17} \mathrm{O}$. The triple oxygen isotope data of Precambrian chert places more specific requirements for various models employed to describe the composition of chert. For instance, through these measurements and associated models we show that changes in the isotopic composition of seawater, and/or elevated Archean surface temperatures are less likely the singular solution for the $\delta^{18} \mathrm{O}$ record - differential diagenetic alteration has almost certainly played an important role. This result broadly corresponds to previous work interpreting $\Delta^{\prime 17} \mathrm{O}$ in chert, but is in contrast to the shale and iron oxide $\delta^{18} \mathrm{O}$ records that suggest a change in seawater crust interac- 
tions $[23,22,21]$. We do note that our analysis can allow for some variance in seawater composition, on the scale suggested elsewhere [24, 54], despite it not statistically being the lone cause. For our data, the most parsimonious solution calls upon equitable surface temperatures, and secondary fluids that look very meteoric in composition $(\approx-15 \%)$ at common subsurface temperatures of a couple hundred degrees. This implies that some, but not necessarily all original information is lost from these phases.

These predictions are consistent with existing $\mathrm{Si}$ and $\mathrm{D} / \mathrm{H}$ isotope data. In the case of $\mathrm{Si}$, there is no correlation (at the $2 \sigma$ level) in the 23 cases where oxygen and Si data are available on the same sample (Figure S8). This is to be expected, as the silicic acid content of alteration fluids would favor the resetting of oxygen long before similar changes were witnessed in silicon. The hydrogen isotopes record in chert has been used to argue for low Archean ocean temperatures [14] - a prediction from this work as well - but arrived at such a conclusion through invoking a temporal change in ocean $\delta^{18} \mathrm{O}$. It is possible that the $\delta \mathrm{D}$ of chert, not being a structural component of the quartz mineral, preserves a different environmental window than that of oxygen.

If, as we argue, the oxygen isotopic composition of Precambrian chert carries a significant component of alteration, then the adjoined prediction is that phosphate, iron oxide, carbonate, and bulk siliciclastics experienced similar histories. These parallel records show a shift in $\delta^{18} \mathrm{O}$ of comparable magnitude over the same time period, but the different oxygen-bearing phases carry differing susceptibilities to alteration. Further work comparing the 
thermodynamic properties of adjacent mineral phases, perhaps using ${ }^{17} \mathrm{O}$ in these actual minerals, or more generally using the model results presented above, will serve to help quantify these co-occurring changes.

In summary, the $\Delta^{117} \mathrm{O}$ record of Precambrian chert is not solely a primary depositional signal. The question remains of how to see through this alteration to a primary composition. Of course, this model (and statistics therein) allow for some change in the $\delta^{18} \mathrm{O}$ of seawater, but are significantly less in keeping with major changes in surface ocean temperatures through time. This contributes to the long-standing debate in the geologic community about the origin of this signal and demonstrates the utility of massdependent, multiple isotope systematics to Earth history questions. 
[1] H. C. Urey, The thermodynamic properties of isotopic substances, Journal of the Chemical Society (Resumed) (1947) 562-581.

[2] J. Zachos, M. Pagani, L. Sloan, E. Thomas, K. Billups, Trends, rhythms, and aberrations in global climate 65 ma to present, Science 292 (2001) 686-693.

[3] N. J. Shackleton, Paleotemperature history of the cenozoic and the initiation of antarctic glaciation: oxygen and carbon isotope analyses in dsdp sites 277,279, and 281, Initial Reports of Deep Sea Drilling Project 29 (1975) 743-756.

[4] J. L. Banner, G. N. Hanson, Calculation of simultaneous isotopic and trace element variations during water-rock interaction with applications to carbonate diagenesis, Geochimica et Cosmochimica Acta 54 (1990) 3123-3137.

[5] M. Schobben, C. V. Ullmann, L. Leda, D. Korn, U. Struck, W. U. Reimold, A. Ghaderi, T. J. Algeo, C. Korte, Discerning primary versus diagenetic signals in carbonate carbon and oxygen isotope records: An example from the permian-triassic boundary of iran, Chemical Geology 422 (2016) 94-107.

[6] L. P. Knauth, Temperature and salinity history of the precambrian ocean: implications for the course of microbial evolution (2005) 53-69. 
[7] L. P. Knauth, S. Epstein, Hydrogen and oxygen isotope ratios in nodular and bedded cherts, Geochimica et Cosmochimica Acta 40 (1976) 10951108.

[8] J. Marin, M. Chaussidon, F. Robert, Microscale oxygen isotope variations in 1.9 ga gunflint cherts: assessments of diagenesis effects and implications for oceanic paleotemperature reconstructions, Geochimica et Cosmochimica Acta 74 (2010) 116-130.

[9] P. Jean-Baptiste, J. Charlou, M. Stievenard, Oxygen isotope study of mid-ocean ridge hydrothermal fluids: Implication for the oxygen-18 budget of the oceans, Geochimica et Cosmochimica Acta 61 (1997) 2669-2677.

[10] J. F. Kasting, M. T. Howard, K. Wallmann, J. Veizer, G. Shields, J. Jaffrés, Paleoclimates, ocean depth, and the oxygen isotopic composition of seawater, Earth and Planetary Science Letters 252 (2006) 82-93.

[11] J. B. Jaffrés, G. A. Shields, K. Wallmann, The oxygen isotope evolution of seawater: A critical review of a long-standing controversy and an improved geological water cycle model for the past 3.4 billion years, Earth-Science Reviews 83 (2007) 83-122.

[12] J. Veizer, A. Prokoph, Temperatures and oxygen isotopic composition of phanerozoic oceans, Earth-Science Reviews 146 (2015) 92-104. 
[13] E. T. Degens, S. Epstein, Relationship between o18/o16 ratios in coexisting carbonates, cherts, and diatomites, AAPG Bulletin 46 (1962) 534-542.

[14] M. Hren, M. Tice, C. Chamberlain, Oxygen and hydrogen isotope evidence for a temperate climate 3.42 billion years ago, Nature 462 (2009) 205.

[15] F. Robert, M. Chaussidon, A palaeotemperature curve for the precambrian oceans based on silicon isotopes in cherts, Nature 443 (2006) 969.

[16] R. E. Blake, S. J. Chang, A. Lepland, Phosphate oxygen isotopic evidence for a temperate and biologically active archaean ocean, Nature 464 (2010) 1029.

[17] G. A. Henkes, B. H. Passey, E. L. Grossman, B. J. Shenton, T. E. Yancey, A. Pérez-Huerta, Temperature evolution and the oxygen isotope composition of phanerozoic oceans from carbonate clumped isotope thermometry, Earth and Planetary Science Letters 490 (2018) 40-50.

[18] P. Ghosh, J. Adkins, H. Affek, B. Balta, W. Guo, E. A. Schauble, D. Schrag, J. M. Eiler, 13c-18o bonds in carbonate minerals: a new kind of paleothermometer, Geochimica et Cosmochimica Acta 70 (2006) $1439-1456$.

[19] J. M. Eiler, clumped-isotope geochemistrythe study of naturally- 
occurring, multiply-substituted isotopologues, Earth and Planetary Science Letters 262 (2007) 309-327.

[20] K. J. Dennis, D. P. Schrag, Clumped isotope thermometry of carbonatites as an indicator of diagenetic alteration, Geochimica et Cosmochimica Acta 74 (2010) 4110-4122.

[21] N. Galili, A. Shemesh, R. Yam, I. Brailovsky, M. Sela-Adler, E. M. Schuster, C. Collom, A. Bekker, N. Planavsky, F. A. Macdonald, et al., The geologic history of seawater oxygen isotopes from marine iron oxides, Science 365 (2019) 469-473.

[22] I. Bindeman, D. Zakharov, J. Palandri, N. D. Greber, N. Dauphas, G. Retallack, A. Hofmann, J. Lackey, A. Bekker, Rapid emergence of subaerial landmasses and onset of a modern hydrologic cycle 2.5 billion years ago, Nature 557 (2018) 545 .

[23] S. Sengupta, A. Pack, Triple oxygen isotope mass balance for the earth's oceans with application to archean cherts, Chemical Geology 495 (2018) 18-26.

[24] D. Zakharov, I. Bindeman, R. Tanaka, G. Friðleifsson, M. Reed, R. Hampton, Triple oxygen isotope systematics as a tracer of fluids in the crust: A study from modern geothermal systems of iceland, Chemical Geology 530 (2019) 119312. 
[25] N. E. Levin, T. D. Raub, N. Dauphas, J. M. Eiler, Triple oxygen isotope variations in sedimentary rocks, Geochimica et Cosmochimica Acta 139 (2014) 173-189.

[26] H. Craig, Isotopic standards for carbon and oxygen and correction factors for mass-spectrometric analysis of carbon dioxide, Geochimica et cosmochimica acta 12 (1957) 133-149.

[27] E. D. Young, A. Galy, H. Nagahara, Kinetic and equilibrium massdependent isotope fractionation laws in nature and their geochemical and cosmochemical significance, Geochimica et Cosmochimica Acta 66 (2002) 1095-1104.

[28] X. Cao, Y. Liu, Equilibrium mass-dependent fractionation relationships for triple oxygen isotopes, Geochimica et Cosmochimica Acta 75 (2011) 7435-7445.

[29] I. Ahn, J. I. Lee, M. Kusakabe, B.-G. Choi, Oxygen isotope measurements of terrestrial silicates using a co 2-laser brf 5 fluorination technique and the slope of terrestrial fractionation line, Geosciences Journal 16 (2012) 7-16.

[30] R. Tanaka, E. Nakamura, Determination of 17o-excess of terrestrial silicate/oxide minerals with respect to vienna standard mean ocean water (vsmow), Rapid Communications in Mass Spectrometry 27 (2013) 285-297. 
[31] A. Pack, D. Herwartz, The triple oxygen isotope composition of the earth mantle and understanding $\delta \mathrm{o} 17$ variations in terrestrial rocks and minerals, Earth and Planetary Science Letters 390 (2014) 138-145.

[32] E. D. Young, L. Y. Yeung, I. E. Kohl, On the $\delta 17$ o budget of atmospheric o2, Geochimica et Cosmochimica Acta 135 (2014) 102-125.

[33] Z. Sharp, J. Gibbons, O. Maltsev, V. Atudorei, A. Pack, S. Sengupta, E. Shock, L. Knauth, A calibration of the triple oxygen isotope fractionation in the sio 2-h 2 o system and applications to natural samples, Geochimica et Cosmochimica Acta 186 (2016) 105-119.

[34] E. D. Young, I. E. Kohl, P. H. Warren, D. C. Rubie, S. A. Jacobson, A. Morbidelli, Oxygen isotopic evidence for vigorous mixing during the moon-forming giant impact, Science 351 (2016) 493-496.

[35] B. R. Cowie, D. T. Johnston, High-precision measurement and standard calibration of triple oxygen isotopic compositions $(\delta 18 \mathrm{o}, \delta 17 \mathrm{o})$ of sulfate by f2 laser fluorination, Chemical Geology 440 (2016) 50-59.

[36] R. Siever, The silica cycle in the precambrian, Geochimica et Cosmochimica Acta 56 (1992) 3265-3272.

[37] A. Knoll, Exceptional preservation of photosynthetic organisms in silicified carbonates and silicified peats, Philosophical Transactions of the Royal Society of London. B, Biological Sciences 311 (1985) 111-122. 
[38] R. G. Maliva, A. H. Knoll, B. M. Simonson, Secular change in the precambrian silica cycle: insights from chert petrology, Geological Society of America Bulletin 117 (2005) 835-845.

[39] P. A. Cohen, J. V. Strauss, A. D. Rooney, M. Sharma, N. Tosca, Controlled hydroxyapatite biomineralization in an 810 million-year-old unicellular eukaryote, Science advances 3 (2017) e1700095.

[40] N. J. Tosca, S. Guggenheim, P. K. Pufahl, An authigenic origin for precambrian greenalite: Implications for iron formation and the chemistry of ancient seawater, Bulletin 128 (2016) 511-530.

[41] W. W. Fischer, A. H. Knoll, An iron shuttle for deepwater silica in late archean and early paleoproterozoic iron formation, Geological Society of America Bulletin 121 (2009) 222-235.

[42] A. Bekker, J. F. Slack, N. Planavsky, B. Krapez, A. Hofmann, K. O. Konhauser, O. J. Rouxel, Iron formation: the sedimentary product of a complex interplay among mantle, tectonic, oceanic, and biospheric processes, Economic Geology 105 (2010) 467-508.

[43] B. Rasmussen, J. R. Muhling, W. W. Fischer, Evidence from laminated chert in banded iron formations for deposition by gravitational settling of iron-silicate muds, Geology 47 (2019) 167-170.

[44] J. Marin-Carbonne, F. Robert, M. Chaussidon, The silicon and oxygen 
isotope compositions of precambrian cherts: A record of oceanic paleotemperatures?, Precambrian Research 247 (2014) 223-234.

[45] H. Bao, M. H. Thiemens, Generation of o2 from baso4 using a co2laser fluorination system for simultaneous analysis of $\delta 180$ and $\delta 17 \mathrm{o}$, Analytical chemistry 72 (2000) 4029-4032.

[46] R. Tartèse, M. Chaussidon, A. Gurenko, F. Delarue, F. Robert, Warm archean oceans reconstructed from oxygen isotope composition of earlylife remnants, Geochemical Perspectives Letters 3 (2017) 55-65.

[47] K. Muehlenbachs, R. Clayton, Oxygen isotope composition of the oceanic crust and its bearing on seawater, Journal of Geophysical Research 81 (1976) 4365-4369.

[48] K. Wallmann, The geological water cycle and the evolution of marine §18o values, Geochimica et Cosmochimica Acta 65 (2001) 2469-2485.

[49] S. Sheppard, H. Gilg, Stable isotope geochemistry of clay minerals, Clay Minerals 31 (1996) 1-24.

[50] L. A. Derry, A burial diagenesis origin for the ediacaran shuram-wonoka carbon isotope anomaly, Earth and Planetary Science Letters 294 (2010) $152-162$.

[51] S. Li, N. E. Levin, L. A. Chesson, Continental scale variation in 170excess of meteoric waters in the united states, Geochimica et Cosmochimica Acta 164 (2015) 110-126. 
[52] B. Luz, E. Barkan, Variations of 17o/16o and 18o/16o in meteoric waters, Geochimica et Cosmochimica Acta 74 (2010) 6276-6286.

[53] R. Chakrabarti, A. H. Knoll, S. B. Jacobsen, W. W. Fischer, Si isotope variability in proterozoic cherts, Geochimica et Cosmochimica Acta 91 (2012) 187-201.

[54] B. Johnson, B. Wing, Archean seawater, Geology (2020).

[55] F. A. Macdonald, P. A. Cohen, F. Ö. Dudás, D. P. Schrag, Early neoproterozoic scale microfossils in the lower tindir group of alaska and the yukon territory, Geology 38 (2010) 143-146.

[56] G. P. Halverson, F. A. Macdonald, J. V. Strauss, E. F. Smith, G. M. Cox, L. Hubert-Théou, Updated definition and correlation of the lower fifteenmile group in the central and eastern ogilvie mountains, Yukon Exploration and Geology (2011) 75-90.

[57] F. A. Macdonald, P. A. Cohen, The tatonduk inlier, alaska-yukon border, Geological Society, London, Memoirs 36 (2011) 389-396.

[58] J. P. Pu, S. A. Bowring, J. Ramezani, P. Myrow, T. D. Raub, E. Landing, A. Mills, E. Hodgin, F. A. Macdonald, Dodging snowballs: Geochronology of the gaskiers glaciation and the first appearance of the ediacaran biota, Geology 44 (2016) 955-958.

[59] D. Chew, C. Kirkland, The Chiquero Formation, southern Peru, 2011. 
[60] F. A. Macdonald, D. S. Jones, Chapter 30 the khubsugul group, northern mongolia 36 (2011) 339-345.

[61] F. A. Macdonald, D. S. Jones, D. P. Schrag, Stratigraphic and tectonic implications of a newly discovered glacial diamictite-cap carbonate couplet in southwestern mongolia, Geology 37 (2009) 123-126.

[62] R. P. Anderson, S. McMahon, U. Bold, F. A. Macdonald, D. E. Briggs, Palaeobiology of the early ediacaran shuurgat formation, zavkhan terrane, south-western mongolia, Journal of Systematic Palaeontology 15 (2017) 947-968.

[63] U. Bold, E. F. Smith, A. D. Rooney, S. A. Bowring, R. Buchwaldt, F. Ö. Dudás, J. Ramezani, J. L. Crowley, D. P. Schrag, F. A. Macdonald, Neoproterozoic stratigraphy of the zavkhan terrane of mongolia: The backbone for cryogenian and early ediacaran chemostratigraphic records, American Journal of Science 316 (2016) 1-63.

[64] S. B. Pruss, T. Bosak, F. A. Macdonald, M. McLane, P. F. Hoffman, Microbial facies in a sturtian cap carbonate, the rasthof formation, otavi group, northern namibia, Precambrian Research 181 (2010) 187-198.

[65] E. F. Smith, F. A. MacDonald, J. L. Crowley, E. B. Hodgin, D. P. Schrag, Tectonostratigraphic evolution of the c. 780-730 ma beck spring dolomite: Basin formation in the core of rodinia, Geological Society, London, Special Publications 424 (2016) 213-239. 
[66] J. V. Strauss, A. D. Rooney, F. A. Macdonald, A. D. Brandon, A. H. Knoll, 740 ma vase-shaped microfossils from yukon, canada: Implications for neoproterozoic chronology and biostratigraphy, Geology 42 (2014) 659-662.

[67] P. K. Strother, A. H. Knoll, E. S. Barghoorn, Micro-organisms from the late precambrian narss\&acirc; rssuk formation, north-western greenland, Palaeontology 26 (1983) 1-32.

[68] V. Sergeev, A. Knoll, P. Y. Petrov, Paleobiology of the mesoproterozoicneoproterozoic transition: the sukhaya tunguska formation, turukhansk uplift, siberia, Precambrian Research 85 (1997) 201-239.

[69] V. N. Sergeev, A. H. Knoll, J. P. Grotzinger, Paleobiology of the mesoproterozoic billyakh group, anabar uplift, northern siberia, Journal of paleontology 69 (1995) 1-37.

[70] P. K. Pufahl, P. W. Fralick, Depositional controls on palaeoproterozoic iron formation accumulation, gogebic range, lake superior region, usa, Sedimentology 51 (2004) 791-808.

[71] A. H. Knoll, B. Simonson, Early proterozoic microfossils and penecontemporaneous quartz cementation in the sokoman iron formation, canada, Science 211 (1981) 478-480.

[72] E. Perry, F. Tan, G. Morey, Geology and stable isotope geochemistry of 
the biwabik iron formation, northern minnesota, Economic Geology 68 (1973) 1110-1125.

[73] J. P. Wilson, W. W. Fischer, D. T. Johnston, A. H. Knoll, J. P. Grotzinger, M. R. Walter, N. J. McNaughton, M. Simon, J. Abelson, D. P. Schrag, et al., Geobiology of the late paleoproterozoic duck creek formation, western australia, Precambrian Research 179 (2010) 135-149.

[74] A. J. Bumby, P. G. Eriksson, O. Catuneanu, D. R. Nelson, M. J. Rigby, Meso-archaean and palaeo-proterozoic sedimentary sequence stratigraphy of the kaapvaal craton, Marine and Petroleum Geology 33 (2012) 92-116.

[75] A. Hofmann, R. Bolhar, B. Orberger, F. Foucher, Cherts of the barberton greenstone belt, south africa: Petrology and trace-element geochemistry of 3.5 to 3.3 ga old silicified volcaniclastic sediments, South African Journal of Geology 116 (2013) 297-322.

[76] S. Kiyokawa, T. Ito, M. Ikehara, F. Kitajima, Middle archean volcanohydrothermal sequence: bacterial microfossil-bearing 3.2 ga dixon island formation, coastal pilbara terrane, australia, Geological Society of America Bulletin 118 (2006) 3-22.

[77] K. Sugitani, Strelley pool formation, Encyclopedia of Astrobiology (2014) 1-7. 
783

784

785

786

787

788

789

[78] B. M. Simonson, K. A. Schubel, S. W. Hassler, Carbonate sedimentology of the early precambrian hamersley group of western australia, Precambrian Research 60 (1993) 287-335.

[79] M. J. Van Kranendonk, Volcanic degassing, hydrothermal circulation and the flourishing of early life on earth: A review of the evidence from c. 3490-3240 ma rocks of the pilbara supergroup, pilbara craton, western australia, Earth-Science Reviews 74 (2006) 197-240. 


\section{Supplementary Information}

\section{1. geological descriptions}

1. The chert-rich, lime-mudstone and grey shale of the Fifteenmile Formation, exposed at Mt. Slipper in west-central Yukon, Canada is our most heavily sampled unit [39]. This section is $810.7+-5.8 \mathrm{Ma}$ according Re-Os geochronology data on the organic rich shale horizon 4.15 meters below the base of our section. Additionally, we report data from 7 samples from a parallel Fifteenmile section one kilometer along strike. This section represents a mixed redox, semi-restricted basinal environment. Samples were deposited below storm wave base in a distal slope setting. Chert is present among all lithologies in the section, allochthonous and autochthonous, but is variable in abundance, distribution, and form. Four samples are specifically from the Hard Luck Creek outcrop and are sourced from a yellow weathering dolomite with common intraclast breccias, black chert nodules, shale interbeds, and molar tooth structures [55]. Like most other Neoproterozoic cherts these were peritidal early replacement nodules. This group was intruded by mafic dikes, but the samples are not taken from directly adjacent. Additional samples are from the peritidal reefal assemblage, a mixed carbonate shale unit slightly lower in the section [56]. Two samples are from Mt Slipper, which are laterally correlative with the Hard Luck Creek samples. These 2 samples are at the top of a dark gray limestone rhythmite unit and are interpreted as subtidal in a shallowing upwards sequence. 
These Yukon samples experienced Anchizone grade metamorphism corresponding to temperatures of 200-300 degrees as part of the orogeny that formed the mountain range [57].

2. Data is provided from the Rocky Harbour Formation in Newfoundland. These are chert clasts from a pistachio colored siliceous siltstone located immediately above 579 Ma age Gaskiers glaciation diamictite [58]. The siltstone contains wavy laminations and dewatering structures on a storm wave ripple surface indicating a deep water depositional environment.

3. Data is provided from the Neoproterozoic San Juan Formation in southern Peru. The section has undergone greenschist facies metamorphism during an Early Paleozoic orogenesis [59]. Stratigraphically, the measured sample $(\mathrm{n}=1)$ is immediately above the inferred Gaskiers cap carbonate and represents the base of the Shuram anomaly. Lithologically, the sample is from a limestone unit above a black shale. Due to a lack of higher energy sedimentary structures this sample is most likely deep marine, but bedding was subsequently disturbed indicating possible alteration (Hodgin personal communication).

4. Data is presented from the Khesen Formation in Khubsugul, Mongolia. These units are peritidal, early replacement chert nodules that precipitated in a dark grey limestone rhythmite. Stratigraphically this unit sits above a glacial diamictite with its associated cap carbonate and disconformably below a phosphorite deposit [60]. 
5. Data is presented from the Zuune Arts Formation in central Mongolia. Samples were taken from a 100 meter thick unit of blue limestone rhythmite and ribbonite. The same unit that includes the black chert nodules also includes meandering ichnogenera. The oldest chert sample from this unit $(\approx 550 \mathrm{Ma})$ is a massive deepwater strataform, suggesting the possible contribution of hydrothermal silica, while the younger two samples $(\approx 544-545 \mathrm{Ma})$ are peritidal early replacement nodules [61].

6. Data are presented from the Shuurgat Formation, a carbonate dominated sequence located between the Zuune Arts Formation above and the post-glacial Ol formation below. Deposition of chert nodules occurred at the maximum flooding surface of a carbonate ramp. Based on the presence of graded beds of flat-laminated micritic limestone with minor grain flows of redeposited ooids these samples formed in a subtidal environment below fair-weather wave-base [62]. The compaction of laminae surrounding the chert nodules indicate that the nodules formed during early diagenesis.

7. Data are presented from the Ol Formation, a carbonate dominated unit deposited immediately after the Marinoan Khongor diamictite. This unit was deposited as part of a transgressive systems tract on an isolated carbonate platform, analogous to the modern Bahama bank [63]. This chert nodule is also a peritidal early replacement nodule, but considering the conditions after the Marinoan may have formed 
under higher-temperatures and equilibrated with low $\delta^{18} O$ meltwater (Liljestrand, in prep).

8. Data are presented from the Cryogenian Taishir Formation, a largely carbonate unit deposited between the Sturtian and Marinoan glaciations. One sample is from a slightly older outcrop $(\approx 660 \mathrm{Ma})$ of limestone calcisiltite and thin-bedded micrite. The sedimentary structures suggest this sample is an early replacement nodule from a sublitoral microbialite, slightly deeper than the common peritidal samples [63]. The 2 younger samples $(\approx 650 \mathrm{Ma})$ are deposited in a calsiltite unit above a flooding surface. These samples are peritidal early replacement nodules and were formed in the midst of a negative $\delta^{13} C$ excursion. Note, these samples as well as the $\mathrm{Ol}$, and Shuurgat, are part of the same Taagaan Olom Group. It and the Zuune Arts formation located unconformably above were weakly metamorphosed as part of the Central Asian Orogenic Belt (CAOB) [63].

9. Data are presented from the Rasthof Formation in Namibia. The Rasthof is a carbonate sequence that immediately postdates the Sturtian diamictite and includes the cap dolostone as well as 200-400 meters of dark gray rhythmite and microbialite [64]. There is no evidence for wave action, which indicates this sample precipitated in the sublittoral zone below wave base. The sample itself was taken from a microbialite so it may be influenced by the climate immediately after snowball and more localized biological processes. 
10. Data are presented from the Beck Springs Formation in Death Valley CA. The Beck Springs is a dolomite unit forming in a broadly transgressive system [65]. The chert samples themselves are peritidal early replacement nodules. Stratigraphically the beck springs immediately predates the Kingston Peak formation which is a diamictite that has been correlated with the Marinoan glaciation.

11. Data are presented from the Callison Lake Formation, a mixed siliciclastic and carbonate deposit located in the Yukon territory of Canada dated to about $745 \mathrm{Ma}$. The chert samples themselves are sourced from a dolostone unit characterized by abundant microbial lamination, domal stromatolitic bioherms, and cross-bedded oolitic grainstone, as well as the early diagenetic chert [66]. Callison Lake strata were formed in a peritidal to shallow subtidal depositional environment in a periodically restricted marginal marine basin.

12. Data are presented from the Akademikerbreen Group, a $\approx 750 \mathrm{Ma}$ Neoproterozoic unit in Svalbard, Norway. The Akademikerbreen group is a 2000 meter succession that hosts a variety of carbonate facies. Petrographic and microfossil evidence suggests that the silica nodules replaced carbonate early in diagenesis, probably on a timescale no more than a few thousand years [53]. Like other early diagenetic chert, these samples probably formed in isolated evaporative coastal environments.

13. Data are presented from the $\approx 1200$ Ma Aorferneq member of the Narssarssuk Formation in northwest Greenland. The chert from 
this unit are early diagenetic in origin, replacing preexisting carbonate microbial mats. These samples likely formed in a broad and geologically relatively stable tidal flat environment varying from subtidal to supratidal [67].

14. Data are presented from the Sukhaya Tunguska Formation in northwestern Siberia. This represents a 1000-1100 year old mixed limestone and dolostone with abundant nodular chert. Chert show evidence of early cementation and environments are largely semi-restricted peritidal with some subtidal and lower intertidal zones. [68]

15. Data are presented from the Billyakh Group in northern Siberia, which samples the Kotiukan and the overlying Yusmastakh formation. The Kotiukan samples are from a chert-rich layer in a broader unit characterized by stromatolitic peritidal dolostones. The Yusmastakh Formation is laminated to medium bedded dolomicrite with abundant though not fossil-rich chert. The Billyakh cherts were likely formed in peritidal environments, possibly semi-restricted and evaporative [69].

16. Data are presented from the $\approx 1860 \mathrm{Ma}$ Ironwood Iron Formationin Michigan. The Ironwood Formation is a Superior type iron formation deposited on a relatively stable cratonic margin. The specific samples are jaspery chert in a granular iron formation, indicating a relatively shallow depositional environment, likely influenced by some current or wave motion [70].

17. Data are presented from the $\approx 1860$ Ma Sokoman Iron Formation 
in Labrador, Canada. The Sokoman is composed of a variety of textures and sedimentary structures [71]. These were likely deposited in relatively shallow water in contact with the open ocean and have been only lightly metamorphosed. Sokoman cherts are granular and show evidence of early silicification, making them more likely to preserve primary isotopic signals [38]. Data are also presented from the Wishart Formation, which underlies the Sokoman Formation. The mineralogy and petrography of the sample is similar.

18. Data are presented from the $\approx 1860$ Ma Biwabak Iron Formation in Minnesota. The outcrop has a stromatolitic texture which places a limit on the possible depth of deposition, primary chert has possibly been subsequently remineralized [72].

19. Data are presented from the $\approx 1860$ Ma Gunflint Iron Formation in Ontario, Canada. The Gunflint is typical of early Proterozoic iron formations, one sample is clearly stromatolitic indicating a low energy shallow depositional environment, the other is more granular indicating a higher energy. The Gunflint Formation has experienced a low degree of metamorphic alteration and has abundant microfossils preserved [38].

20. Data are presented from the 1865 Ma Duck Creek Formation. The Duck Creek is primarily dolomite with minor associated iron formation. The sample comes from chert pods that are themselves associated with the iron formation [73].

21. Data are presented from the 2060 Ma Franceville Group in Gabon. 
Not primarily an iron formation, instead this sample comes from a stromatolitic black chert.

22. Data are presented from the 2709 Ma Rietgat Formation in the Ventersdorp Supergroup in South Africa. The Ventersdorp Supergroup is primarily volcanic, the Rietgat is a silicified carbonate located stratigraphically between two flood basalt units. The sample is stromatolitic in origin and probably represents a peritidal environment [74].

23. Data are presented from the 3250 Ma Fig Tree Group in South Africa. The Fig Tree Gp. is a mixed shallow water and volcanic sequence. The samples are from relatively minor banded iron formations [75].

24. Data are presented from the 3000 Ma Cleaverville Formation from the George Creek Group in Australia. This sample is from a massive chert bed, possibly deposited in a relatively deep subtidal environment and silicified quickly. The unit is bounded by volcanic rocks, but has experienced only low grade metamorphism [76].

25. Data are presented from the 2684 Ma Jeerinah Formation from the Fortescue Group in Australia. The sample is from a carbonate unit in the Jeerinah that immediately overlies a sandstone bed and precedes a black shale. The black chert formed as a replacement of the carbonate and the formation has experienced minor low temperature metamorphism.

26. Data are presented from the 3390 Ma Strelley Pool Formation in Australia. The Strelley Pool formation covers a range of shallow water 
to terrestrial depositional environments and associated lithologies. This chert probably formed as an early diagenetic carbonate replacement in a shallow water evaporitic environment [77].

27. Data are presented from the 3462 Ma Kromberg Formation in the Onverwacht Group South Africa. The Kromberg formation has both bedded (sampled here) and vein associated chert[75].

28. Data are presented from the $2550 \mathrm{Ma}$ Wittenoom Formation from the Hamersley Supergroup in Australia. The specific sample measured here is a chert nodule in basinal carbonates. The sample is relatively well preserved for an Archean age unit [78].

29. Data are presented from the Tower and Apex formations, both of which are in the $3000 \mathrm{Ma}$ Warrawoona Supergroup. The apex chert is a minor phase bedded in a larger basalt unit, the Tower Formation is immediately below the Apex Formation stratigraphicaly [79].

\subsection{XRD information}

Samples were analyzed at the University of Oxford on a Panalytical Empyrean Series 2 powder X-ray diffractometer using a Co Ka source at $40 \mathrm{kV}$ and $40 \mathrm{~mA}$. Samples were prepared as randomly oriented aggregates by mixing with ethanol and spread on zero background silicon single crystal substrates. Background subtraction, peak statistics, phase identification, and quantification were performed using HighScore Plus software. Quantification was performed with the reference intensity ratio method using scale 
996

997

998

factors recently compiled in the International Center for Diffraction Data (ICDD) Powder Diffraction File 4+.

\section{3. supporting figures}

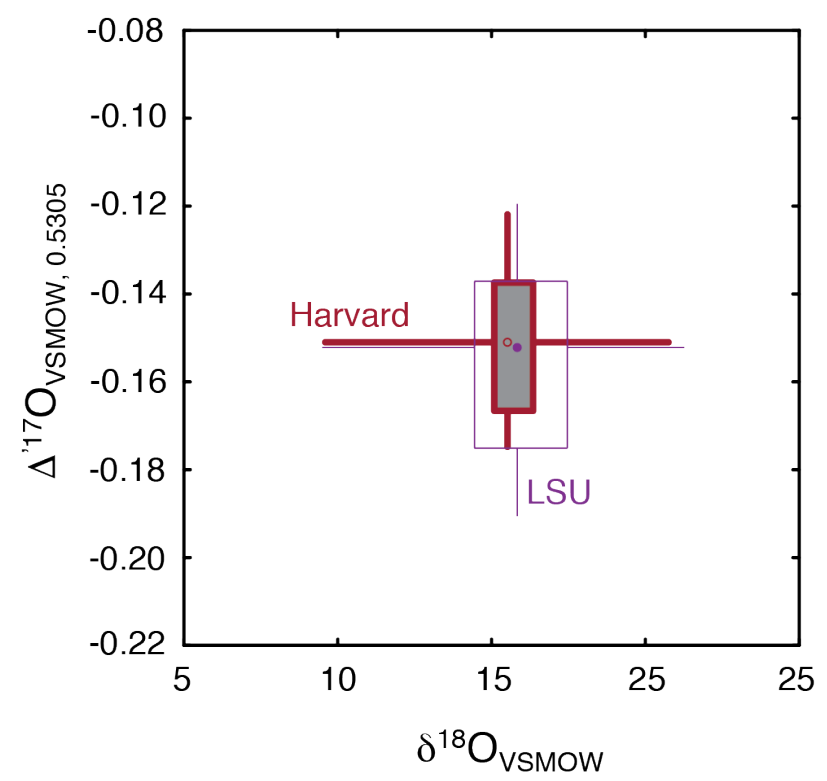

Figure S1: Comparison of $\delta^{18} \mathrm{O}$ and $\Delta^{17} \mathrm{O}$ for Archean chert samples that were measured at both LSU and Harvard. A) Shows the raw data with associated error bars of $\pm 0.019 \%$ from Harvard and $\pm 0.023 \%$. B) Shows the same data as a box and whisker plot to better compare the relative means. The points represent the means, the boxes represent 25-75 percentile, the whiskers represent the 5-95 percentile. 


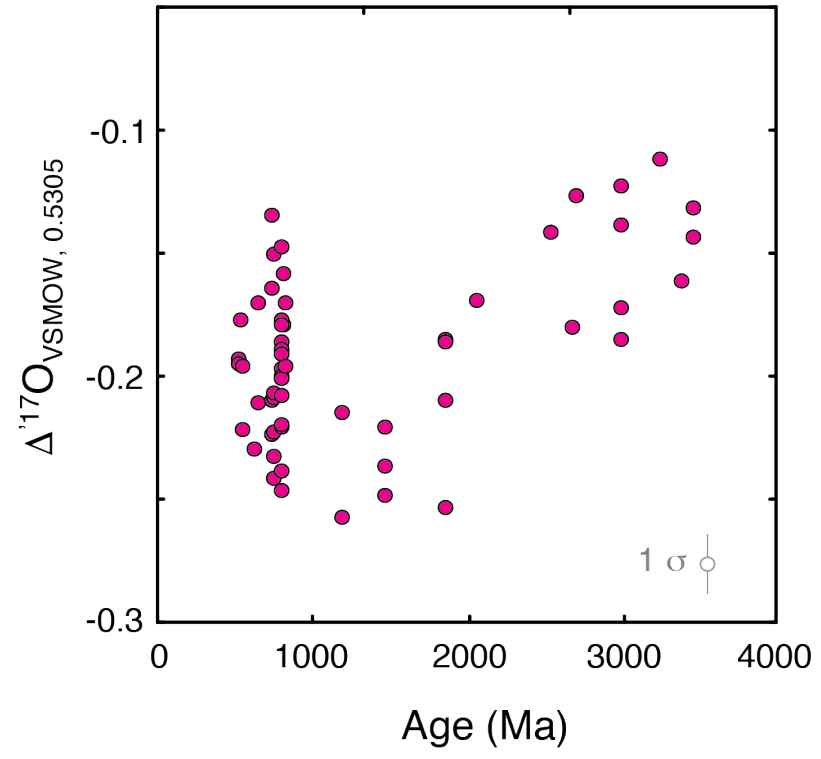

Figure S2: A plot of the mineralogically vetted $\Delta^{\prime 17} \mathrm{O}$ compositions through time. Error is captured in the lower left of the frame.

\begin{tabular}{llllll}
\hline Sample ID & Age (Ma) & Origin & $\delta^{17} \mathrm{O}$ & $\delta^{18} \mathrm{O}$ & $\Delta^{917} \mathbf{O}$ \\
\hline \hline
\end{tabular}

See attached file. height

Table S1: Triple oxygen isotope data for Archean chert as measured at LSU and Harvard. All data is reported in \%o units relative to VSMOW and $\Delta^{17} \mathrm{O}$ values are normalized relative to $\lambda=0.5305$. Both datasets were normalized relative to the same literature values of San Carlos Olivine, NBS-28, and UWG-2. The mean difference between $\Delta^{, 17} \mathrm{O}$ as measured at Harvard and LSU is $0.0012 \%$ 

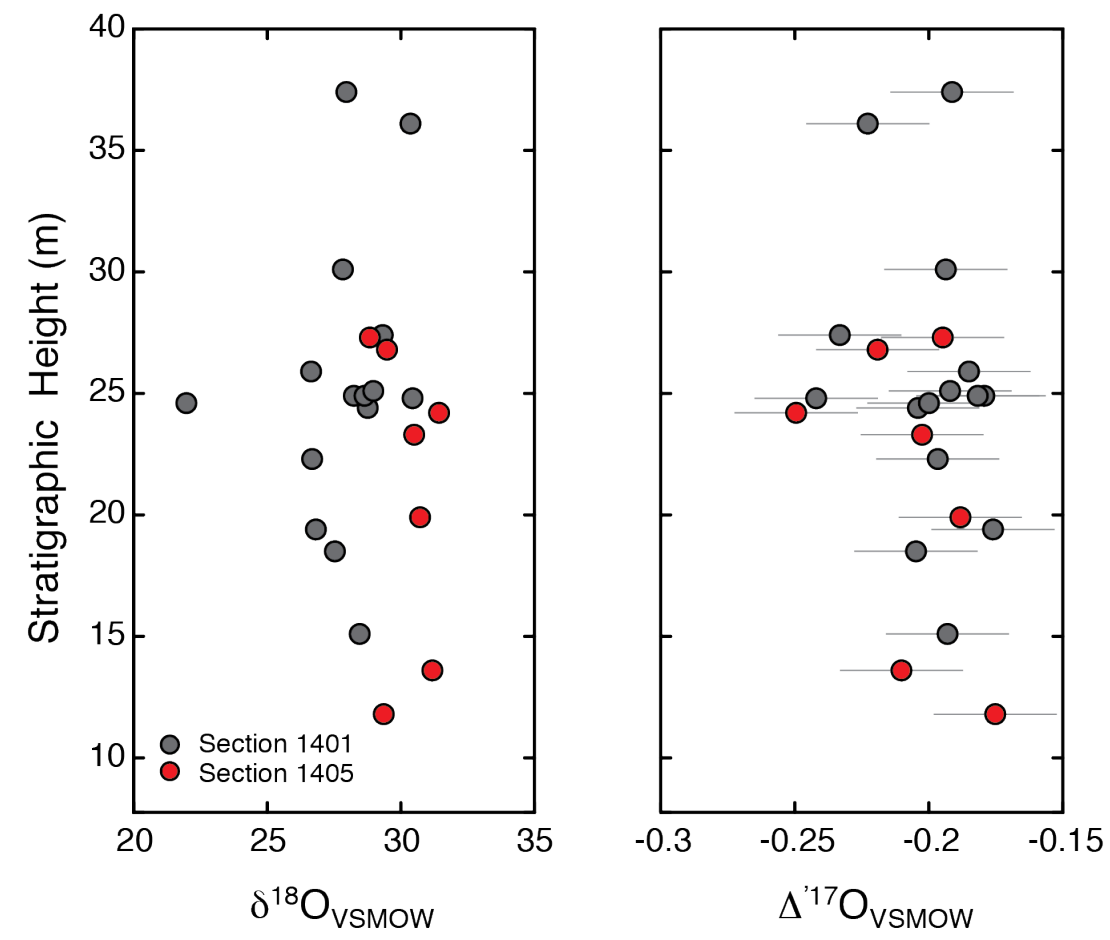

Figure S3: Oxygen isotope data of the stratigraphic test at the Fifteenmile formation. The red and gray data are from different parallel outcrops of the same formation. As can be seen, the oxygen isotope signal, especially in the minor isotope, is indistinguishable.

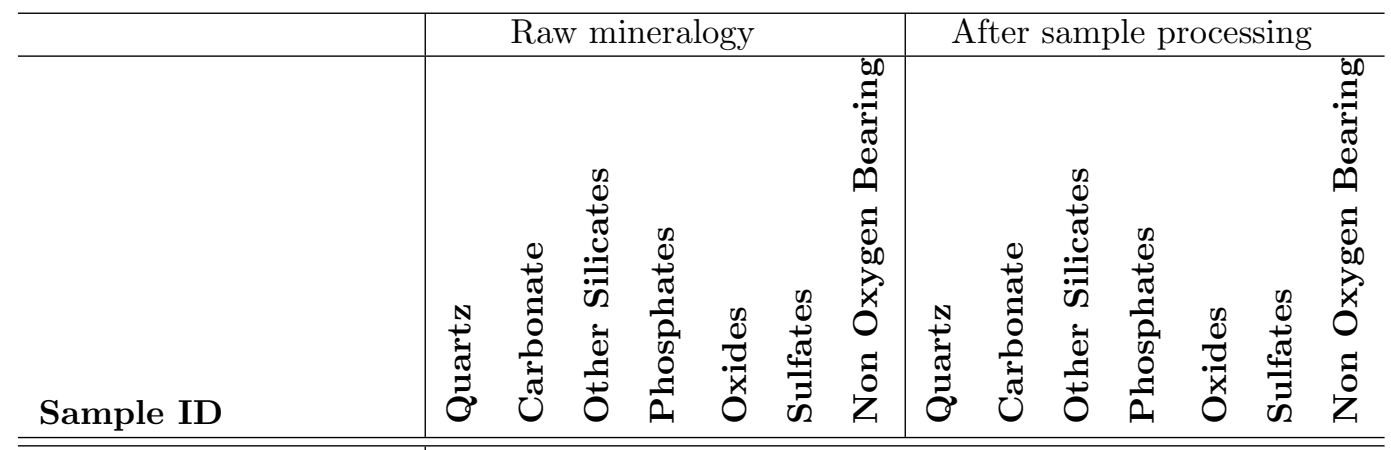

See attached file. height

Table S2: Data from mineralogical analyses. 

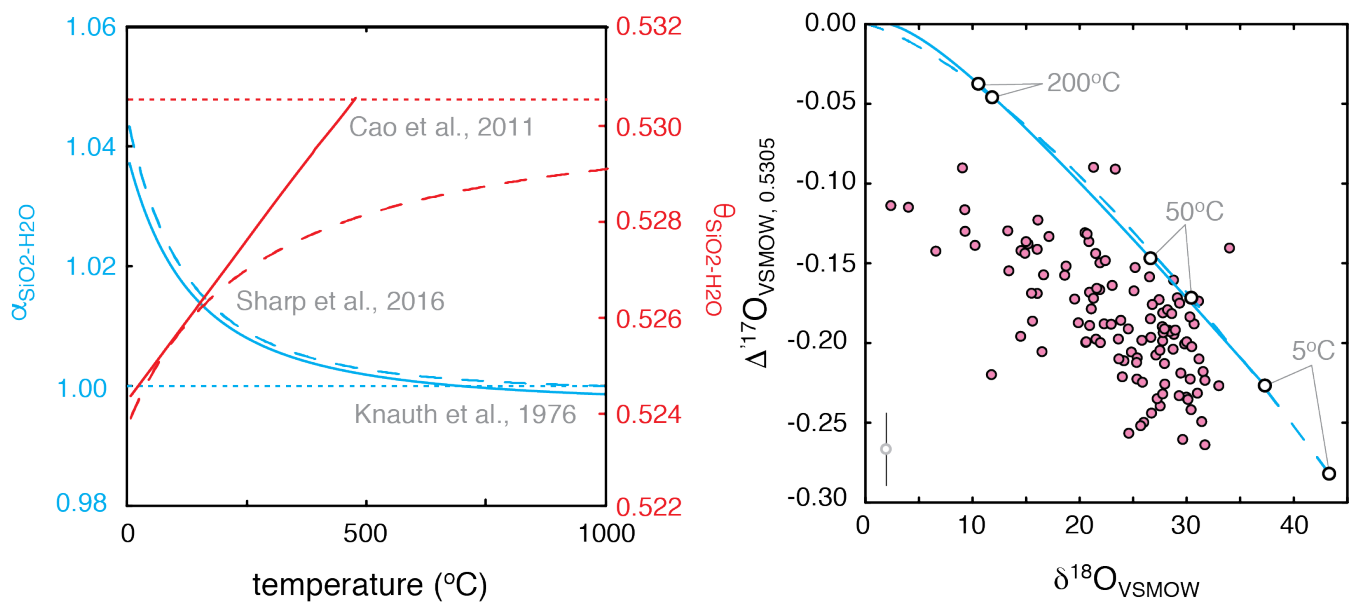

Figure S4: At left, we include the temperture dependent fractionation factorsused in this analysis. At right, the model prediction with no diagenesis, no change in seawater chemistry, but changing surface temperatures (i.e. precipitation temperatures). Together these temperature predictions combine in $\Delta^{17} \mathrm{O}-\delta^{18} \mathrm{O}$ space to form concave down arrays that do not pass through the data. The different colored lines here represent the different temperature dependencies from the left frame.

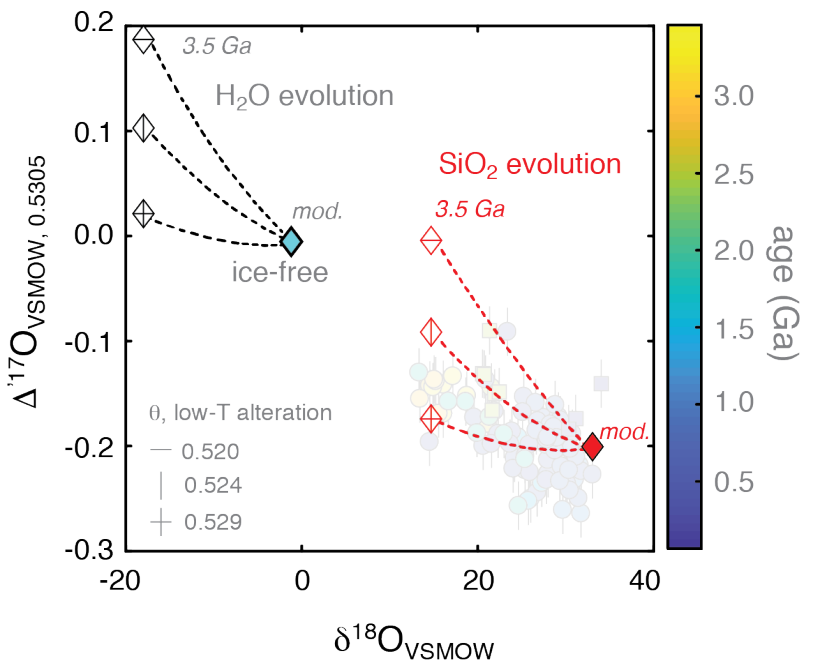

Figure S5: The triple isotope prediction associated with differential crustal interactions is sensitive to the choice of input fractionation factors. Here, we keep the 1.028 effect in $\delta^{18} \mathrm{O}$, and explore the consequences for other values of $\theta$. Note that 0.524 is the preferred values, based on measurements of oceanic crust [23] 

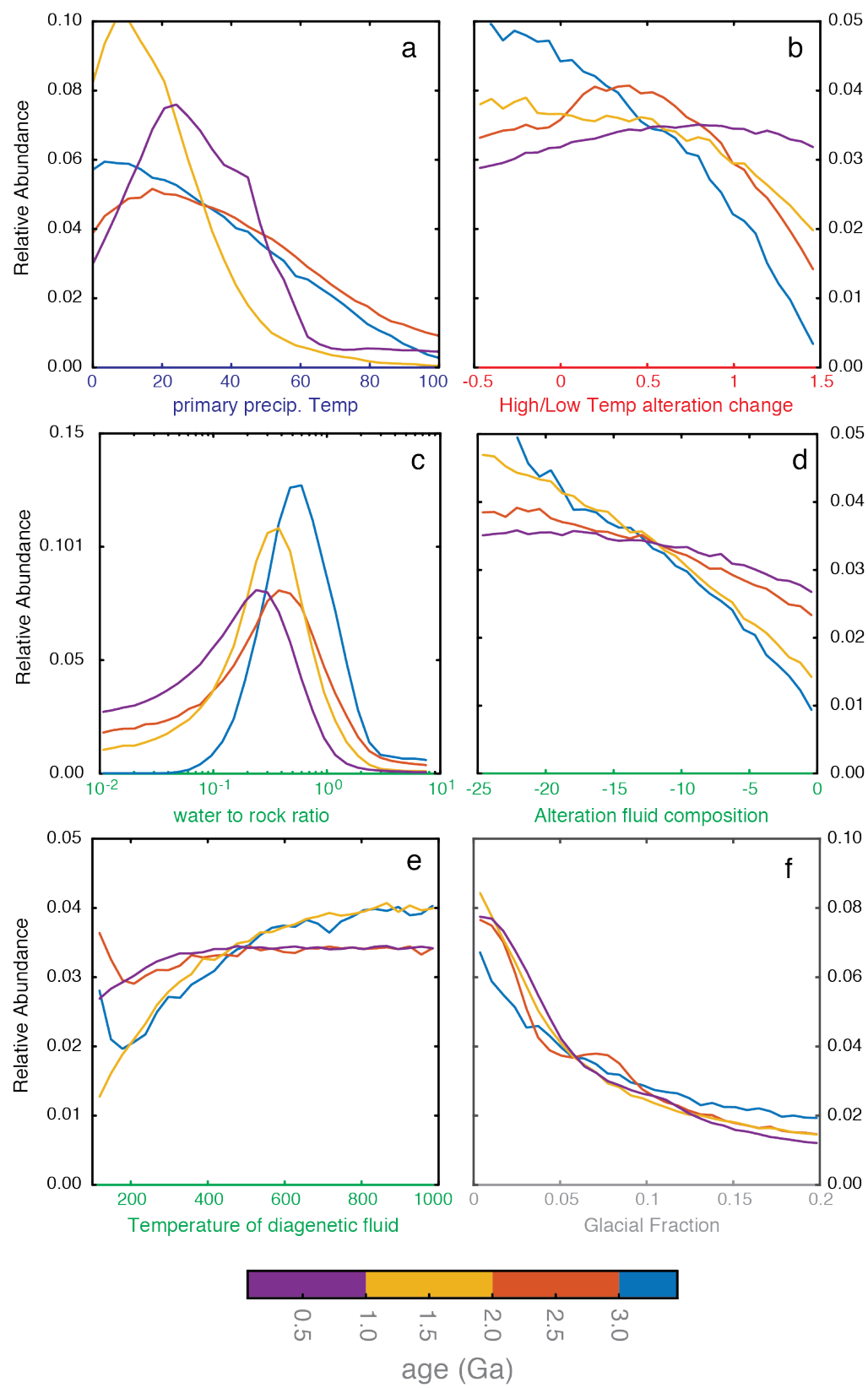

Figure S6: To evaluate whether building a bulk solution was losing information about temporal evolution, here we bin solutions by time, allowing for an additional layer of interpretation. 


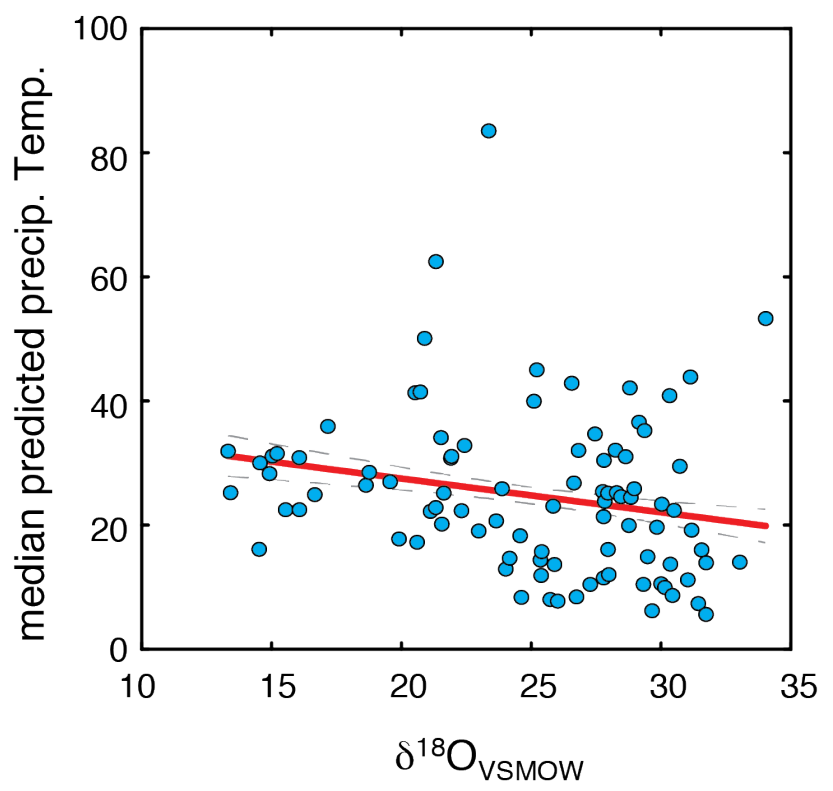

Figure S7: Measured $\delta^{18} \mathrm{O}$ of the chert samples against the Monte Carlo predicted precipitation temperature. The statistics reflect the linear best fit for each dataset.
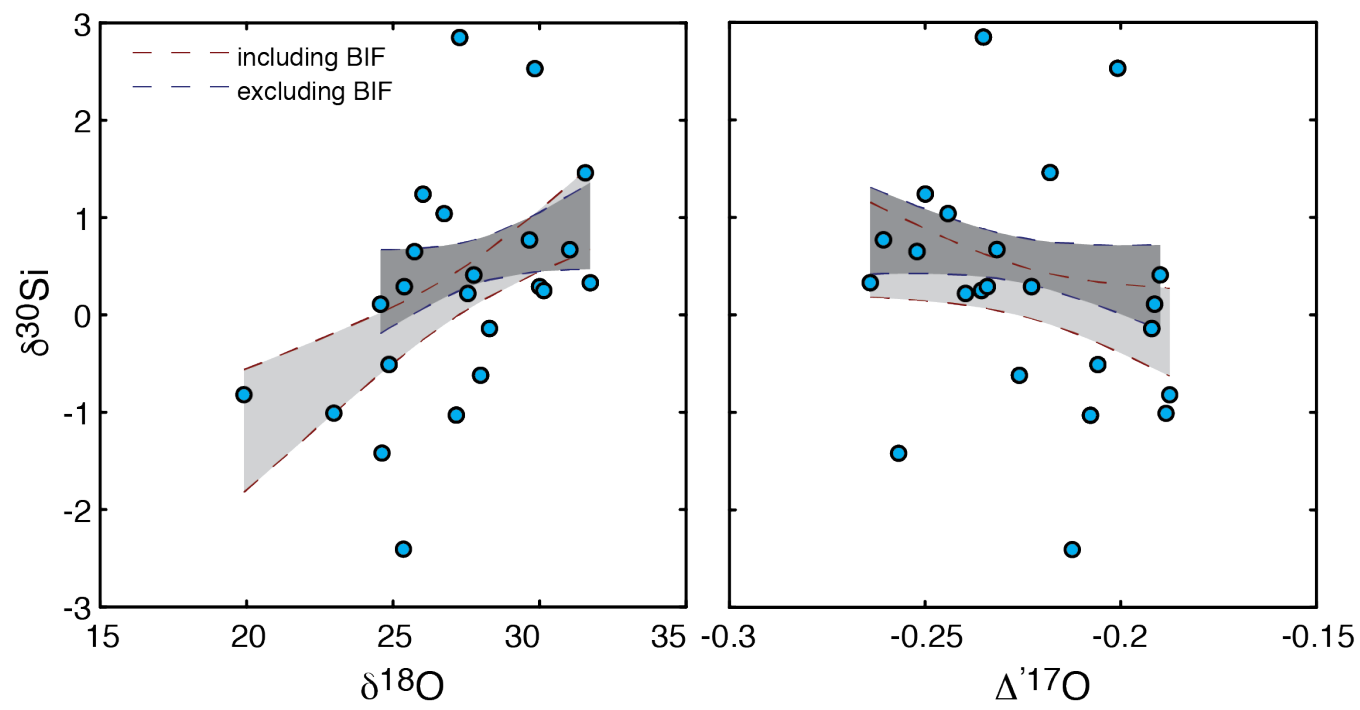

Figure S8: Comparison of the previously measured $\delta^{30}$ Si data with the new oxygen isotope compositions [53]. Red points are cherts associated with Paleoproterozoic BIF, Blue points are Proterozoic peritidal chert. The only statistically significant relationship $(\mathrm{P}<0.05)$ exists between $\delta^{18} \mathrm{O}$ and $\delta^{30} \mathrm{Si}$ specifically when the BIF samples are included. 


\begin{tabular}{|c|c|c|}
\hline Variable & Allowed Range & Description \\
\hline $\begin{array}{l}\text { ocean change } \\
\text { fraction }\end{array}$ & -0.5 to 1.5 & $\begin{array}{l}\text { The degree to which the ocean compo- } \\
\text { sition is allowed to evolve, held con- } \\
\text { stant when at } 0 \text {, follows described } \\
\text { ocean change prediction when at } 1 \text {, and } \\
\text { scales proportionally for other values. }\end{array}$ \\
\hline $\begin{array}{l}\text { glacial } \\
\text { fraction }\end{array}$ & 0 to 0.2 & $\begin{array}{l}\text { Fraction of the ocean volume stored } \\
\text { as ice, also approximates the degree of } \\
\text { evaporation in an enclosed basin. }\end{array}$ \\
\hline $\begin{array}{l}\text { precipitation } \\
\text { temperature }\end{array}$ & 0 to 100 & $\begin{array}{l}\text { Equilibrium temperature at which the } \\
\text { chert originally precipitates. Con- } \\
\text { strained to temperatures at which the } \\
\text { ocean is liquid. }\end{array}$ \\
\hline $\begin{array}{l}\text { water to rock } \\
\text { ratio }\end{array}$ & 0.01 to 10 & $\begin{array}{l}\text { Defines the degree to which samples are } \\
\text { altered, value can theoretically range } \\
\text { from zero to infinity, but the three or- } \\
\text { ders of magnitude here cover reason- } \\
\text { able variability. }\end{array}$ \\
\hline $\begin{array}{l}\text { groundwater } \\
\delta^{18} \mathrm{O}\end{array}$ & -25 to 0 & $\begin{array}{l}\delta^{18} \mathrm{O} \text { Isotopic composition of ground- } \\
\text { water with which alteration occurs. } \\
\text { groundwater } \Delta^{17} \mathrm{O} \text { is constrained by } \\
\text { this value according to the relationship } \\
\text { described in Luz et al. } 2010 \text { [52]. }\end{array}$ \\
\hline $\begin{array}{l}\text { diagenesis } \\
\text { temperature }\end{array}$ & 100 to 1000 & $\begin{array}{l}\text { Equilibrium temperature at which the } \\
\text { chert is diagenetically altered. Lower } \\
\text { bound is set at } 100 \text { to ensure alteration } \\
\text { always occurs at a temperature above } \\
\text { original precipitation. }\end{array}$ \\
\hline
\end{tabular}

Table S3: Variables included in the Monte Carlo model of chert formation 


\begin{tabular}{|c|c|c|c|c|c|c|c|}
\hline & & & & & & \multirow{2}{*}{\multicolumn{2}{|c|}{ LSU Replicat }} \\
\hline \multirow{2}{*}{ ID } & \multirow[b]{2}{*}{ Age (Ma) } & \multicolumn{4}{|c|}{ LSU Replicate 1} & & \\
\hline & & $\delta^{18} 0$ & $\delta^{17} 0$ & $\Delta^{17} 0 \_0.5305$ & $\Delta^{17} 0 \_0.528$ & $\delta^{18} 0$ & $\delta^{17} 0$ \\
\hline M602-607 a. & 525 & 14.52 & 7.48 & -0.196 & -0.160 & & \\
\hline M602-607 b. & 525 & 21.56 & 11.18 & -0.198 & -0.144 & & \\
\hline M620-1.1 a. & 540 & 16.52 & 8.52 & -0.206 & -0.165 & & \\
\hline M620-1.1 b. & 540 & 15.63 & 8.07 & -0.186 & -0.148 & & \\
\hline M622-169 & 544 & 23.39 & 12.16 & -0.179 & -0.121 & 26.82 & 13.98 \\
\hline M622-146.5 & 545 & 20.10 & 10.57 & -0.047 & 0.003 & 26.63 & 13.90 \\
\hline M622-85 a. & 550 & 25.84 & 13.43 & -0.198 & -0.135 & & \\
\hline M622-85 b. & 550 & 25.90 & 13.43 & -0.225 & -0.161 & & \\
\hline F726-165B a. & 600 & 23.75 & 12.32 & -0.208 & -0.150 & 24.00 & 12.50 \\
\hline F726-165B b. & 600 & 23.65 & 12.28 & -0.198 & -0.139 & & \\
\hline F723-58 a. & 632 & 16.13 & 8.40 & -0.123 & -0.083 & & \\
\hline F723-58 b. & 632 & 27.79 & 14.41 & -0.232 & -0.164 & & \\
\hline F704-330 a. & 650 & 19.56 & 10.16 & -0.173 & -0.124 & & \\
\hline F704-330 b. & 650 & 20.37 & 10.54 & -0.214 & -0.163 & 20.84 & 10.82 \\
\hline F704-331 a. & 650 & 22.32 & 11.59 & -0.188 & -0.133 & & \\
\hline F704-331 b. & 650 & 20.97 & 10.88 & -0.189 & -0.137 & & \\
\hline F702-100 & 660 & 24.02 & 12.45 & -0.221 & -0.162 & & \\
\hline B1419-921.0 a. & 555 & 6.60 & 3.35 & -0.143 & -0.126 & & \\
\hline B1419-921.0 b. & 555 & 11.73 & 5.98 & -0.227 & -0.198 & 11.86 & 6.06 \\
\hline TP1 & 579 & 10.26 & 5.29 & -0.139 & -0.113 & & \\
\hline TP2 & 579 & 9.05 & 4.70 & -0.089 & -0.067 & 9.12 & 4.73 \\
\hline TP3 & 579 & 9.30 & 4.81 & -0.117 & -0.093 & & \\
\hline F8013A a. & 660 & 23.07 & 12.01 & -0.164 & -0.107 & & \\
\hline F8013A b. & 660 & 20.64 & 10.69 & -0.199 & -0.148 & & \\
\hline F901-33.8 & 739 & 20.89 & 10.89 & -0.137 & -0.085 & & \\
\hline F901-20 & 740 & 21.91 & 11.39 & -0.167 & -0.113 & & \\
\hline F930_5.5 & 740 & 27.96 & 14.52 & -0.213 & -0.144 & & \\
\hline F927-64.5 & 745 & 33.03 & 17.16 & -0.227 & -0.146 & & \\
\hline F929_37.5 a. & 750 & 24.17 & 12.53 & -0.211 & -0.152 & & \\
\hline F929_37.5 b. & 750 & 25.21 & 13.14 & -0.153 & -0.091 & & \\
\hline $81 B-550$ & 750 & 28.12 & 14.61 & -0.209 & -0.140 & 28.46 & 14.82 \\
\hline 86P-108-3 & 750 & 30.00 & 15.57 & -0.234 & -0.160 & & \\
\hline $86 P-96-2 A$ & 750 & 30.14 & 15.64 & -0.236 & -0.161 & & \\
\hline $81 P-4705-2 B$ & 750 & 26.74 & 13.85 & -0.244 & -0.178 & & \\
\hline $81 B-625-2 A$ & 750 & 27.99 & 14.52 & -0.226 & -0.157 & & \\
\hline T-714-1 & 770 & 27.16 & 14.11 & -0.208 & -0.141 & & \\
\hline T-714-2 & 770 & 24.86 & 12.91 & -0.206 & -0.144 & & \\
\hline T705-18 a. & 805 & 30.03 & 15.62 & -0.199 & -0.125 & & \\
\hline T705-18 b. & 805 & 31.74 & 16.48 & -0.224 & -0.145 & & \\
\hline T705-18 c & 820 & 29.15 & 15.19 & -0.172 & -0.100 & & \\
\hline T705-154.2 & 812 & 27.80 & 14.47 & -0.181 & -0.113 & & \\
\hline T705-123.6 & 815 & 28.80 & 15.01 & -0.161 & -0.090 & & \\
\hline P1405-11.8 & 810.7 & 29.42 & 15.35 & -0.150 & -0.077 & 29.31 & 15.24 \\
\hline P1405-13.6 & 810.7 & 31.18 & 16.21 & -0.210 & -0.133 & & \\
\hline
\end{tabular}


LaTeX Source Files
Click here to download LaTeX Source Files: The Geologic Record of $\$^{\wedge}\{17$ (1).zip

LaTeX Source Files
Click here to download LaTeX Source Files: The Geologic Record of $\$^{\wedge}\{17$ (1).zip Click here to download LaTeX Source Files: The Geologic Record of $\$ \wedge 17(1)$ zip

(2)

$\sqrt{2}$

$\sqrt{3}$

(1) (1) (1) (1) .

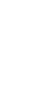

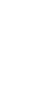

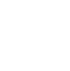

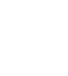

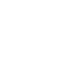

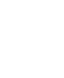

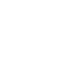
更

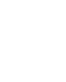

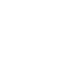

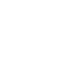

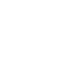

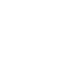

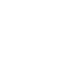

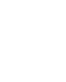

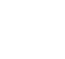




\section{Author declaration}

[Instructions: Please check all applicable boxes and provide additional information as requested.]

\section{$\underline{\text { 1. Conflict of Interest }}$}

Potential conflict of interest exists:

$\mathrm{X} \square$ No conflict of interest exists.

We wish to confirm that there are no known conflicts of interest associated with this publication and there has been no significant financial support for this work that could have influenced its outcome.

\section{Funding}

$\square$ Funding was received for this work.

All of the sources of funding for the work described in this publication are acknowledged below:

[List funding sources and their role in study design, data analysis, and result interpretation]

XNo funding was received for this work.

\section{$\underline{\text { 3. Intellectual Property }}$}

XWe confirm that we have given due consideration to the protection of intellectual property associated with this work and that there are no impediments to publication, including the timing of publication, with respect to intellectual property. In so doing we confirm that we have followed the regulations of our institutions concerning intellectual property.

\section{$\underline{\text { 4. Research Ethics }}$}

XWe further confirm that any aspect of the work covered in this manuscript that has involved human patients has been conducted with the ethical approval of all relevant bodies and that such approvals are acknowledged within the manuscript.

$\square$ IRB approval was obtained (required for studies and series of 3 or more cases) 
$\square$ Written consent to publish potentially identifying information, such as details or the case and photographs, was obtained from the patient(s) or their legal guardian(s).

\section{$\underline{5 . \text { Authorship }}$}

The International Committee of Medical Journal Editors (ICMJE) recommends that authorship be based on the following four criteria:

1. Substantial contributions to the conception or design of the work; or the acquisition, analysis, or interpretation of data for the work; AND

2. Drafting the work or revising it critically for important intellectual content; AND

3. Final approval of the version to be published; AND

4. Agreement to be accountable for all aspects of the work in ensuring that questions related to the accuracy or integrity of any part of the work are appropriately investigated and resolved.

All those designated as authors should meet all four criteria for authorship, and all who meet the four criteria should be identified as authors. For more information on authorship, please see http://www.icmje.org/recommendations/browse/roles-andresponsibilities/defining-the-role-of-authors-and-contributors.html\#two.

XAll listed authors meet the ICMJE criteria. We attest that all authors contributed significantly to the creation of this manuscript, each having fulfilled criteria as established by the ICMJE.

$\square$ One or more listed authors do(es) not meet the ICMJE criteria.

We believe these individuals should be listed as authors because:

XWe confirm that the manuscript has been read and approved by all named authors.

XWe confirm that the order of authors listed in the manuscript has been approved by all named authors.

\section{Contact with the Editorial Office}

The Corresponding Author declared on the title page of the manuscript is:

DAVID JOHNSTON 
XThis author submitted this manuscript using his/her account in EVISE.

XWe understand that this Corresponding Author is the sole contact for the Editorial process (including EVISE and direct communications with the office). $\mathrm{He} / \mathrm{sh}$ is responsible for communicating with the other authors about progress, submissions of revisions and final approval of proofs.

XWe confirm that the email address shown below is accessible by the Corresponding Author, is the address to which Corresponding Author's EVISE account is linked, and has been configured to accept email from the editorial office of American Journal of Ophthalmology Case Reports:

johnston@eps.harvard.edu

$\square$ Someone other than the Corresponding Author declared above submitted this manuscript from his/her account in EVISE:

[Insert name below]

$\square$ We understand that this author is the sole contact for the Editorial process (including EVISE and direct communications with the office). He/she is responsible for communicating with the other authors, including the Corresponding Author, about progress, submissions of revisions and final approval of proofs.

We the undersigned agree with all of the above.
Author's name (Fist, Last)
Signature
Date

1. _David Johnston

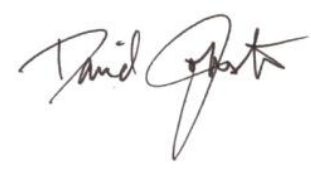

$10 / 22 / 2019$ 
${ }^{*}$ Author Contributions Section

Author contributions statement:

Frasier L. Liljestrand and David T. Johnston: conceptualization, modeling

Frasier L. Liljestrand, David Johnston, Yongbo Peng, Nick Tosca: data collections and analysis.

Phoebe A. Cohen, Francis A. Macdonald, Andrew H. Knoll: sample curation

All authors contributed to the writing of this manuscript. 